\title{
Mass Litigation Governance in the Post-Class Action Era: The Problems and Promise of Non-removable State Actions in Multi- district Litigation
}

\author{
J. Maria Glover \\ Georgetown University Law Center, mglover@law.georgetown.edu
}

This paper can be downloaded free of charge from:

https://scholarship.law.georgetown.edu/facpub/1333

http://ssrn.com/abstract=2425606

\section{J. Tort L. 1-44 (2014)}

This open-access article is brought to you by the Georgetown Law Library. Posted with permission of the author. Follow this and additional works at: https://scholarship.law.georgetown.edu/facpub

Part of the Courts Commons, Litigation Commons, and the Torts Commons 


\title{
Article
}

J. Maria Glover*

\section{Mass Litigation Governance in the Post-Class Action Era: The Problems and Promise of Non-removable State Actions in Multi-district Litigation}

\begin{abstract}
Given a string of decisions restricting the use and availability of the class action device, the world of mass litigation may well be moving into a postclass action era. In this era, newer devices of aggregation-perhaps principally among them multi-district litigation ("MDL")-increasingly will be called upon to meet the age-old mass litigation goal of achieving global peace of numerous claims arising out of a related, widespread harm. Indeed, coordination of pretrial proceedings in the MDL frequently facilitates the achievement of this peace, given the reality that cases, once consolidated in the MDL, often settle en masse.

However, one clear obstacle to the achievement of aggregate peace in the MDL, one that also plagues the achievement of that peace in the class action world, is our federal system of substantive and procedural law. In the MDL context, the problem arises because litigation involving state-law claims and non-diverse parties, which are not removable from state court, cannot be transferred to the MDL court. Despite their prevalence, little scholarly attention has been devoted to non-removable state-court actions in MDL. The few responses to this issue have largely focused upon the efficiencies that could be gained through increased, and perhaps total, consolidation of all related cases or, short of consolidation, through heightened coordination of pre-trial proceedings between state and federal judges.
\end{abstract}

This Article questions whether these responses have led reform proposals in the wrong direction, and instead takes a different view. Rather than argue for increased consolidation, I offer for further consideration the possible ways in which the happenstantial existence of parallel tracks of related state and federal cases actually hold promise, if properly harnessed, as mechanisms for achieving the goals of aggregate litigation and for disciplining the contours of global settlements of mass disputes. In particular, I explore the possibility that the existence of parallel state and federal cases-frequently viewed as an obstacle to global resolution of claims unable to be consolidated in a single forum-may well fortuitously provide an opportunity to achieve the sorts of mass litigation 
resolution envisioned but unsuccessfully attempted in the class action context. 1 In so doing, this Article adds new thoughts and theories to the specific debate regarding parallel state and federal claims in MDL, as well as to the larger debate about mass litigation governance in a post-class action world.

*Corresponding author: J. Maria Glover, Georgetown University Law Center, Washington, DC, USA, E-mail: mglover@law.georgetown.edu

\section{Q3 Introduction}

In the world of mass litigation, claimants, judges, and attorneys alike remain on a quest to achieve global peace of countless, but related, lawsuits. Yet the paradigmatic mechanism for achieving this elusive goal-the class action device-has been more enfeebled than ever, both by limitations inherent in the device itself and by limitations increasingly imposed by the courts. Indeed, reading the Supreme Court's recent class action cases and the corresponding scholarly literature on class actions, ${ }^{1}$ one might wonder whether, in the world of mass litigation, it is "the end of the world as we know it."2

While I do not think that we have seen the last of the class action, ${ }^{3}$ recent developments have put increasing pressure on other mechanisms of aggregation

1 Am. Exp. Co. v. Italian Colors Restaurant, 133 S.Ct. 2304 (2013); Comcast Corp. v. Behrend, 13325 S.Ct. 1426 (2013); Wal-Mart Stores, Inc. v. Dukes, 131 S.Ct. 2541 (2011); AT\&T Mobility LLC v. Concepcion, 131 S.Ct. 1740 (2011); Stolt-Nielsen S.A. v. AnimalFeeds International Corp., 559 U.S. 662 (2010); see also Ortiz v. Fibreboard Corp., 527 U.S. 815 (1999); Amchem Products, Inc. v. Windsor, 521 U.S. 591 (1997); Myriam Gilles, Procedure in Eclipse: Group-Based Adjudication in a Post-Concepcion Era, 56 St. Lous U. L.J. 1203 (2012); Myriam Gilles, Opting Out of Liability: The Forthcoming, Near-Total Demise of the Modern Class Action, 104 Mich. L. Rev. 373 (2005); Myriam 30 Gilles \& Gary Friedman, After Class: Aggregate Litigation in the Wake of AT\&T Mobility v. Concepcion, 79 U. CHI. L. Rev. 623 (2011); Linda S. Mullenix, Aggregate Litigation and the Death of Democratic Dispute Resolution, 107 Nw. U. L. Rev. 511 (2013); Linda S. Mullenix, Federal Class Actions: A Near-Death Experience in Shady Grove, 79 Geo. WASH. L. Rev. 448 (2011); Maria Glover \& Charles Silver, Zombie Class Actions, Scotusblog (Sept. 8, 2011, 10:16 AM), http://www. scotusblog.com/2011/09/zombie-class-actions/.

2 R.E.M., IT's the End of the World as We Know It (And I Feel Fine), (Sound Emporium 1987). Just to be clear, I do not feel particularly "fine" about the end of the class action world. The end of the class action world as we know it? Maybe.

3 See, e.g., Dodd-Frank Wall Street Reform and Consumer Protection Act, Pub. L. No. 111-203, $\S$ 921, 124 Stat. 1376, 1841 (2010) (amending 15 U.S.C. $\S 780$ to allow the SEC to prohibit predispute arbitration agreements of federal securities claims). 
for the hopeful achievement of globalized peace in overlapping disputes. The 1 most prominent of these is federal multi-district litigation ("MDL"). Even without formal aggregation of claims through the class action device, the MDL process allows consolidation and coordination of multiple-related lawsuits, at least as to pre-trial matters. Given that MDL cases are no exception to the rule that cases 5 overwhelmingly settle rather than go to trial, ${ }^{4}$ coordination of pre-trial matters frequently facilitates the achievement of peace among the various parties involved on an aggregate basis. Further, given the strictures of commonality, typicality, and predominance found in Fed. R. Civ. P. 23-at least as those strictures have been interpreted by courts-the MDL is an important device 10 that enables parties to effectuate global settlements that could not be implemented through the class action.

There is one glaring obstacle, however, to the MDL as a mechanism for achieving aggregate peace outside the context of the class action: our federal system of both substantive and procedural law. This problem has beleaguered 15 the class action device as well, where differing state laws, even on the same subject, can be deemed to constitute intra-class conflicts that disable the use of the class action under Rule 23, and possibly under the Due Process Clause of the Constitution. ${ }^{5}$ In the MDL context, the problem arises because litigation involving state-law claims and non-diverse parties, which are not removable from 20 state court, cannot be transferred to the MDL court. The Judicial Panel on MultiDistrict Litigation (JMPL) does not "have the power ... to consider the propriety of coordinated or consolidated pretrial proceedings in state court actions." 6 These state-court cases thus pose a potential obstacle to the use of the MDL as a vehicle for the achievement of global peace in the context of mass litigation.

Despite the prevalence of these state cases, little scholarly attention has been devoted to the problem of non-removable state-court actions in MDL. To the extent that the problem has been addressed, the responses have focused largely on calls either for procedural mechanisms to provide increased, and

4 See Richard A. Nagareda, Mass Torts In A World Of Settlement 224 (2007) (describing the consolidation of cases in MDL as a "springboard for negotiations aimed at comprehensive peace”); Thomas E. Willging \& Emery G. Lee III, From Class Actions to Multidistrict Consolidations: Aggregate Mass Tort Litigation After Ortiz, 58 U. Kan. L. Rev. 775, 801 (2010) 35 (noting that the "MDL process has supplemented and perhaps displaced the class action device as a procedural mechanism for large settlements").

5 Phillips Petroleum Co. v. Shutts, 472 U.S. 797 820-23 (1985) (rejecting a putative class action that would apply Kansas law to claims subject to the laws of a variety of other states).

6 In re Celotex Corp. “Technifoam” Prod. Liab. Litig., 68 F.R.D. 502, 503 n. 2 (J.P.M.L. 1975); see also 28 U.S.C. $\S 1407(\mathrm{a})$. 
perhaps total, consolidation of all related cases ${ }^{7}$ or, short of consolidation, for 1 heightened coordination of pre-trial proceedings between state and federal judges. ${ }^{8}$ Congress, too, has taken some steps in this direction. ${ }^{9}$ The impulse behind both sets of responses is simple and compelling: duplicative discovery and other pre-trial litigation wastes the time and resources of both the judiciary 5 and of parties; moreover, a number of dispersed proceedings involving a multiplicity of plaintiffs, plaintiffs' attorneys, judges, and even juries risks producing inconsistent outcomes, encouraging strategic gamesmanship, and impeding the achievement of peace on an aggregate scale. Indeed, to the extent parallel state cases can be understood as individual components of what is more appropri- 10 ately understood as a single mass litigation, ${ }^{10}$ the federal characteristics of our judicial system may create significant impediments to the goals of efficiency, consistency, and finality central to aggregate litigation. ${ }^{11}$

While the impulse to overcome federalism as an obstacle to the efficient resolution of mass litigation is understandable, it is worth reconsidering whether 15 that impulse has led reform proposals in the wrong direction. For starters, no amount of procedural consolidation can overcome the reality that, under the entrenched Erie doctrine, state-court cases (and even some federal diversity cases) within an MDL will necessarily be resolved under state substantive law. Absent a systemic shift to nationalized products liability law, differences in the 20 underlying rule of decision will limit the capacity of procedural consolidation to

7 See, e.g., Martin H. Redish, Intersystemic Redundancy and Federal Court Power: Proposing A Zero Tolerance Solution to the Duplicative Litigation Problem, 75 Notre Dame L. Rev. 1347 (2000); Martin H. Redish, Reassessing the Allocation of Judicial Business Between State and Federal Courts: Federal Jurisdiction and the "Martian Chronicles," 78 VA. L. Rev. 1768 (1992); William W. Schwarzer, et al., Judicial Federalism: A Proposal to Amend the Multidistrict Litigation Statute to Permit Discovery Coordination of Large-Scale Litigation Pending in State and Federal Courts, 73 TEx. L. Rev. 1529 (1995) [hereinafter Judicial Federalism].

8 See, e.g., Conference of Chief Justices [CCJ], Directing the National Center for State Courts to 30 Promote Communication and Best Practices for the Management of Like-Kind Litigation That Spans Multiple State Jurisdictions and Federal Districts, CCJ Midyear Meeting Res. 2 (Jan. 26, 2011), available at http://ncsc.contentdm.oclc.org/cdm/ref/collection/federal/id/71; Catherine R. Borden \& Emery G. Lee III, Beyond Transfer: Coordination of Complex Litigation in State and Federal Courts in the Twenty-First Century, 31 Rev. LiTig. 997, 1007 n. 48 (2012); Francis E. McGovern, Toward a Cooperative Strategy for Federal and State Judges in Mass Tort Litigation, 35 148 U. PA. L. Rev. 1867 (2000); Francis E. McGovern, Rethinking Cooperation Among Judges in Mass Tort Litigation, 44 UCLA L. Rev. 1851 (1997).

9 See infra Part II.B.

10 See, e.g., Richard Nagareda, Embedded Aggregation in Civil Litigation, 95 CoRnell L. Rev. 1105, 1107-15 (2010).

11 Principles of the Law of Aggregate Litigation $\$ 1.03$ (2010). 
achieve outcomes in mass litigation. Moreover, as a practical matter, the long- 1 standing conception of federal courts as courts of limited jurisdiction makes removal jurisdiction over all related state-court cases unlikely to materialize.

This piece comes at the problem of non-removable state-court cases in MDL from a different perspective than previously taken, namely, from the perspective 5 of global settlement as a means of governance through litigation. It seeks to (1) situate the problem of non-removable state cases within a larger framework about structuring mass litigation in a post-class action era and (2) suggest consideration of the ways in which the existence of parallel tracks of related state and federal cases hold promise, if properly harnessed, as mechanisms for 10 achieving the goals of aggregate litigation and for meeting the challenges presented by the reality that mass litigation settlements occupy an important regulatory role in the American legal system.

In so doing, I do not argue that state-court proceedings in mass litigation are the best mechanisms, or the only mechanisms, by which such objectives could 15 be achieved. Nor do I argue in favor of or against our system of federalism; rather, I take that system as a given. I leave for future work broader questions about whether the world of mass litigation requires a new theory of federalism and about the contours of such a theory. Indeed, it is important to note at the outset that, to the extent federalism could be harnessed in service of better mass 20 litigation governance, that reality is fortuitous, or accidental, as it is connected to federalism. In other words, and as I discuss in this piece, federalism may foster conditions that would aid in mass litigation governance, but those conditions do not stem from the typically cited purposes or values underlying federalism itself. Accordingly, one might term any potential promise federalism holds 25 in aiding mass litigation governance as "happenstantial federalism."

In this Article, I explore the possibility that this "happenstantial federalism"this existence of parallel state and federal cases, often seen as an obstacle to global resolution of claims unable to be consolidated in a single forum-may well fortuitously provide an opportunity to achieve the sorts of mass litigation resolu- 30 tion envisioned but unsuccessfully attempted in the class action context. Specifically, this Article explores the idea that mass litigation may well benefit from the calculated and targeted harnessing of some sub-set of the non-removable state cases to aid in mass litigation governance by disciplining settlement grids. I argue that these non-removable state cases could help discipline mass litigation 35 settlements in four key ways: one, by providing needed real-world data for use in any ultimate settlement grid; two, by ensuring greater legitimacy of those settlements as mechanisms of governance; three, by potentially making any ultimate settlements fairer to litigants; and four, by providing settlement finality through greater assurance that any resulting settlement terms will stick. 
This paper proceeds in three parts. Part I provides a very brief account of 1 parallel state and federal actions in the context of MDL. Part II discusses the responses, from scholars, members of the judiciary, and Congress, to the problems associated with the non-removability of state cases into federal MDL proceedings. These responses focus largely on increasing consolidation or infor- 5 mal coordination of state-court cases to eliminate duplicative litigation and increase overall efficiency. Part III then considers the non-removability of the state actions from a different perspective-one that considers the potential promise that series of independent proceedings may hold in the development of mass litigation settlements.

\section{Part I: the problem of non-removable state actions in MDL}

In MDL, civil actions that involve one or more common questions of fact and are 15 pending in different district courts may be transferred to a single court for consolidated or coordinated pretrial proceedings. ${ }^{12}$ Actions may be transferred to the MDL at the discretion of the Judicial Panel on Multidistrict Litigation ("JPML"), provided that it determines that such transfers will serve the convenience of the parties and witnesses and will promote the just and efficient 20 conduct of the actions. ${ }^{13}$ These transfers can be initiated by the JPML sua sponte or by the motion of a party, ${ }^{14}$ and the JPML may also separate any claim against any party and remand it to its original forum. ${ }^{15}$ Once it has decided to consolidate certain civil actions, the JPML will select a transferee federal district court to handle all further pretrial proceedings in the transferred cases. ${ }^{16}$ That 25 single transferee court will then preside over discovery and render rulings on all pretrial matters. ${ }^{17}$ Finally, at the conclusion of pretrial proceedings, the transferee court must (absent agreement by the parties) remand each action back to

12 See 28 U.S.C. § 1407(a) (2006).

13 Id.

14 Id. § 1407(c).

15 Id. § 1407(a).

16 Id. § 1407(c).

17 See id. Furthermore, the Panel may designate any district court the transferee regardless of whether it would have had territorial jurisdiction over all the defendants individually. See, e.g., 35 In re Aviation Prod. Liab. Litig., 347 F. Supp. 1401 (J.P.M.L. 1972) ("Transfer of civil actions pursuant to 28 U.S.C. $\S 1407$ is for pretrial purposes only and the fact that all parties are not amenable to suit in a particular district does not prevent transfer to that district for pretrial proceedings where the prerequisites of Section 1407 are otherwise satisfied." (citing In re Kauffman Mut. Fund Actions, 337 F. Supp. 1337, 1339 (J.P.M.L. 1972))). But see In re Motor Fuel Temperature Sales. Pracs. Litig., 711 F.3d 1050 (9th Cir. 2013). 
its original district for trial. ${ }^{18}$ Usually, however, such remand never occurs 1 because consolidation in the MDL serves to facilitate a global settlement. ${ }^{19}$

Currently, the MDL statute provides no mechanism for consolidating or coordinating litigation in state courts. ${ }^{20}$ The JPML lacks "the power under Section 1407 to consider the propriety of coordinated or consolidated pretrial 5 proceedings in state court actions." 21 Thus, mass litigation that spawns multiple lawsuits will often involve state-court actions that cannot be removed to federal court and thus remain on a separate track from the MDL. ${ }^{22}$ In contrast with a broadly defined, nationwide class (putting aside the thorny problem of whether such a class could be certified), state-law claims that do not qualify for federal 10 diversity jurisdiction are beyond the reach of the MDL. ${ }^{23}$

1828 U.S.C. § 1407(a); see also Lexecon, Inc. v. Milberg Weiss Bershad Hynes \& Lerach, 523 U.S. 26, 40-41 (1998) (holding that the plain reading of 28 U.S.C. § 1407 prohibited transferee courts from using 28 U.S.C. 1404 to avoid transferring MDL cases back to their original courts).

19 Howard M. Erichson \& Benjamin Zipursky, Consent versus Closure, 96 CoRnell L. Rev. 265, 270 (2011) (MDL “creates the perfect conditions for an aggregate settlement”); Deborah Hensler, Has the Fat Lady Sung? The Future of Mass Toxic Torts, 26 Rev. Litig. 883, 893 (2007) (“[A]lthough formally intended only to streamline the pretrial process, multi-districting usually leads to some sort of aggregative disposition.”); Deborah R. Hensler, The Role of Multi-Districting in Mass Tort Litigation: An Empirical Investigation, 31 Seton Hall L. Rev. 883, 894 (2001).

20 Edward F. Sherman, Aggregate Disposition of Related Cases: The Policy Issues, 10 Rev. Litig. 231, 234 (1991) (The available mechanisms for aggregation are "frequently powerless to insure the efficient aggregation of cases because jurisdictional barriers and federalism constraints prevent a comprehensive disposition of related cases in the same form.”); Judicial Federalism, supra note 7, at $1531 \mathrm{n}$. 15 (noting that federal class actions and bankruptcy proceedings have 25 the potential to override state court jurisdiction of particular claims, but generally do not achieve intersystem aggregation).

21 In re Celotex Corp. “Technifoam” Prod. Liab. Litig., 68 F.R.D. 502, 503 n. 2 (J.P.M.L. 1975); David F. Herr, Limitations on Panel's Power-No Power Over State Court Cases, in Multidistrict Litigation Manual § 3:13 (2013 ed.) ("Perhaps the most serious limitation on the Panel's power is its inability to facilitate coordinated or consolidated pretrial proceedings in actions that are pending 30 in both state and federal courts. The Panel has no authority over actions pending in state court."). 22 A recent Supreme Court case, Smith v. Bayer Corp., 131 S. Ct. 2368 (2011), illustrates the implications of this limit on the JPML, and thus the federal transferee court. There, after a transferee court had denied class certification, it enjoined a state court from considering a different plaintiff's request to approve a similar class action against the same defendant. The Supreme Court found that such an injunction was beyond the transferee court's authority under 35 the "relitigation exception" to the Anti-Injunction Act. See id. at 2373. A corollary of this finding is that plaintiffs may pursue their own overlapping claims for certification in state court even if similar classes were rejected in the MDL.

23 See Judicial Federalism, supra note 7, at 1531 n. 15 (noting that federal class actions are one of the few procedural mechanisms that has the potential to override state court jurisdiction of particular claims). 
The problem of parallel state court proceedings in the context of MDL 1 litigation is a significant one. Recent studies reveal that a third of all pending federal civil cases are part of MDL proceedings. Further, products liability cases-the very sorts of claims that are typically brought under state law and for which federal jurisdiction may not exist ${ }^{24}$-make up nearly $90 \%$ of the raw 5 number of cases in MDL. The predictable result is that MDL litigation often will proceed alongside related, but unconsolidated state-court cases that cannot be removed to federal court or consoldiated to the transferee court. I surveyed all pending MDL proceedings between August and November $2013^{25}$ and determined that, in 52\% of those proceedings, plaintiffs had filed at least one related 10 state-court action that could not be consolidated with the federal MDL. ${ }^{26}$ Moreover, in $80 \%$ of the pending products-liability cases, plaintiffs had filed at least one related state-court action.

As just one example, in October 2009, the JPML consolidated all federal cases involving claims that Pfizer's smoking cessation drug, Chantix, caused a 15 number of serious medical injuries in the U.S. District Court for the Northern District of Alabama. ${ }^{27}$ Yet state-court cases alleging similar products liability claims against Pfizer relating to Chantix had been filed and continued to be litigated in New York ${ }^{28}$ and Illinois state courts. ${ }^{29}$ As another example, alongside federal MDL No. 2262, In re: LIBOR-based Financial Instruments Antitrust 20 Litigation, which involves antitrust, unjust enrichment, and restitution claims for the manipulation of the London Interbank Offered Rate (LIBOR), are

24 Andrew D. Bradt, The Shortest Distance: Direct Filing and Choice of Law in Multidistrict Litigation, 88 Notre Dame L. Rev. 759, 784 n. 140 (2012) (citing Emery G. Lee, et al., The Expanding Role of Multidistrict Litigation in Federal Civil Litigation: An Empirical Investigation 2 (2010) (manuscript on file with author)); see also Andrew S. Pollis, The Need for Non-Discretionary Interlocutory Appellate Review in Multidistrict Litigation, 79 FoRDHAM L. Rev. 1643, 1666-67 (2011) (noting same figures). Furthermore, the MDLs themselves are often incredibly expansive, 30 encompassing "thousands of cases filed by legions of attorneys." Charles Silver \& Geoffrey C. Miller, The Quasi-Class Action Method of Managing Multidistrict Litigations: Problems and a Proposal, 63 VAND. L. Rev. 107, 115 (2010).

25 As of November 14, 2013, there were 248 MDL proceedings pending.

26 Of those 248 pending MDL proceedings, 75 involve products liability claims.

27 In re Chantix (Varenicline) Products Liability Litigation, 655 F. Supp.2d (J.P.M.L. 2009).

28 See Branden Samuels, Chantix Lawsuits Move Forward in New York, Chantix Lawsuit Center (July 18, 2011), http://chantixlawsuit-info.com/2011/07/chantix-lawsuits-move-forward-newyork/. Four underlying cases in New York's mass action are active or scheduled for trial. As of October 2013, twenty-eight underlying cases are listed as active on the New York state docket, dating between December 2010 and February 2012.

29 See e.g., Hamrin v. Pfizer, Inc., No. 2009-L-005113 (Ill. Ct. Cl. filed Apr. 30, 2009). 
shareholder derivative claims and state fraud-based claims in New York, ${ }^{30}$ and 1 three breach of fiduciary duty, foreclosure, and various property and contract claims in Virginia. ${ }^{31}$

Not only are state-court cases not consolidated with the federal MDL, but the level of state-court organization and consolidation of these parallel proceedings 5 varies greatly. States with well-developed systems of intra-state coordination of related litigation include New York and New Jersey, ${ }^{32}$ where specific mass tort aggregation mechanisms not only permit the consolidation of related claims within the state-court system but also provide for coordination with federal MDL courts. Toward the middle of the spectrum are states like Illinois, ${ }^{33}$ which do 10 have limited coordination mechanisms, but where courts infrequently consolidate related actions. ${ }^{34}$ On the opposite end of the spectrum are states-such as

30 See Ruckert v. Bercherer, No. 652196/2013 (N.Y. Sup. Ct. filed June 21, 2013); Salix Capital US

Inc. v. Bank of America Securities LLC, No. 65182/2013 (N.Y. Sup. Ct. filed May, 21, 2013); Sealink Funding Ltd. v. Credit Suisse Holding, No. 652962/2012 (N.Y. Sup. Ct. filed August 23, 2012); Raul v. Bramble, No. 651677/2011 (N.Y. Sup. Ct. filed June 15, 2011); Zucker v. Rubin, No. 651580/ 2011 (N.Y. Sup. Ct. filed June 8, 2011). All claims arise from the LIBOR manipulation scheme also alleged in the federal MDL.

31 See Nanfuka v. Wells Fargo Bank, No. CL13001318 (Va. Cir. filed May 7, 2013); Banks v. Deutsche Bank National, No. 2013-011036 (Va. Cir. filed July 3, 2013); Feinberg v. JPMorgan Chase Bank, No. 2013-004342 (Va. Cir. filed Mar. 1, 2013). As here, the number of parallel actions increases significantly if one identifies state proceedings that run parallel to cases initiated by the Department of Justice. Antitrust cases are generally instructive. For example, alongside federal MDL No. 1952, In re: Packaged Ice Antitrust Litigation, were, at minimum, two indepen- 25 dent federal cases and two state claims in Texas. Over fifteen parallel cases also proceeded against MDL No. 1952 defendants in New York, Maryland, Florida, Georgia, Nevada, Illinois, South Carolina, and Oklahoma. (That said, while these cases appear related based upon docket information, the lack of complaint-specific information may mitigate their informational utility). Likewise, in the products liability MDL No.1699, In re: Bextra and Celebrex Marketing Sales Practices and Product Liability Litigation, New York and New Jersey mass actions, each with over 30 1,000 claims, proceeded alongside the federal MDL.

32 Other states with well-developed, formal mechanisms for coordination of intra-state cases include California, Colorado, Connecticut, Maryland, Massachusetts, Oklahoma, Pennsylvania, Rhode Island, Texas, Virginia, West Virginia, and Wisconsin.

33 States with arrangements and limitations similar to that of Illinois include Arizona, Indiana, Kansas, Missouri, Minnesota, Nevada, New Hampshire, North Dakota, Oregon, South Carolina, 35 and Tennessee.

34 The infrequency of intra-state consolidation, notwithstanding the existence of some coordination mechanism, is a result of (1) the statutory consolidation scheme's failure to authorize cross-county consolidation by lower courts; and (2) the lack of a centralized e-filing system. Accordingly, large-scale consolidation generally occurs only at the behest of the Illinois Supreme Court. 
Florida, Delaware, and Georgia ${ }^{35}$ - where little meaningful consolidation data is 1 available because of the absence of one or more of the following: (1) formalized coordination mechanisms for related intra-state cases; (2) jurisdiction for Supreme Court supervisory authority of lower courts; and (3) unified, statewide electronic filing systems. In those instances, therefore, the limited instances of 5 coordination are party-initiated.

In short, the current system leaves a significant number of non-removable state-court cases unable to be consolidated in the federal MDL. This phenomenon is particularly acute given that an overwhelming number of MDL proceedings involves state-law claims that often cannot be removed to federal court. 10 Cases brought in states that lack their own procedural mechanisms for consolidation of related state-court cases further complicate the problem. The nonremovability of these state cases thus poses a significant obstacle to MDL's goal of consolidating related proceedings for purposes of facilitating the efficient resolution of mass litigation.

\section{Part II: responses to the problem of non-removable state actions in multidistrict litigation}

Despite the scope of the issue, there has been relatively little scholarly attention paid to the problem that non-removable state cases pose for federal MDL proceedings. This section consolidates (no pun intended) the leading responses by scholars and judges, as well the responses so far undertaken by Congress. At their core, these responses share a common impulse: Further mechanisms are 25 needed to reduce if not eliminate the inefficiencies and potential inconsistent outcomes created by non-removable state-court cases.

\section{A Scholarly and judicial responses to overlapping state and federal cases} in MDL

The leading responses by scholars and judges to the issue of parallel state actions in MDL can be categorized into two groups. The first involves suggestions for formal procedural mechanisms of inter-system consolidation of the state-court actions. The second set of responses attempts not to consolidate

35 Additional states with no meaningful mechanisms for coordination include Alabama, Alaska, Arkansas, Hawaii, Idaho, Iowa, Kentucky, Louisiana, Maine, Mississippi, Missouri, Montana, Nebraska, New Mexico, North Carolina, Ohio, South Dakota, Utah, Vermont, Washington, and Wyoming. 
formally the federal and state cases in one forum, but suggests instead that state 1 and federal judges engage in more informal modes of coordination, particularly on pre-trial matters.

In the former group, and perhaps at the furthest end of the reform spectrum, is Martin Redish's "zero-tolerance" model for duplicative litigation. ${ }^{36}$ This model 5 proposes an "alternative jurisdictional structure" in which any assertion of federal jurisdiction automatically would preclude the continued conduct of parallel state litigation through a federal-court-issued injunction. ${ }^{37}$ In the alternative, should the federal court fail to issue such an injunction, that failure would constitute the equivalent of the federal court's abstention from the related 10 cases on its docket. ${ }^{38}$ Redish argues that those interested "primarily or exclusively in avoiding the burdens and inefficiencies caused by litigation duplication would presumably care little which of these two courses the federal court would choose."39 Along similar lines, other scholars have advocated the creation of federal mass-tort legislation, ${ }^{40}$ or for the creation of specialized disaster courts 15 to handle mass litigation. ${ }^{41}$

Still falling within the first group of reform proposals but occupying a more moderate place on the spectrum are those suggestions for adjustments to current MDL procedures. The leading proposal of this type comes from Judge William Schwarzer, who has become convinced that ad hoc coordination arrangements 20 among state and federal judges presiding over related cases are insufficient to reduce the inefficiencies of duplicative litigation. ${ }^{42}$ Accordingly, Schwarzer has proposed an amendment to the existing MDL statute to provide for limited

36 See Redish, Intersystemic Redundancy, supra note 7.

37 Id. at 1349.

38 Id. at $1355-61$.

39 Id. at 1349.

40 Linda S. Mullenix, Mass Tort Litigation and the Dilemma of Federalization, 44 DePaul L. Rev. 775,775 (1995) (discussing the possibility of substantive mass-tort legislation as a way to "solve" 30 the array of mass-tort litigation problems).

41 Ralph I. Lancaster \& Catherine R. Connors, Creation of a National Disaster Court: A Response to "Judicial Federalism in Action," 78 VA. L. REv. 1753 (1992) (suggesting that informal arrangements between federal and state judges have their costs, and that creation of a national disaster court may be a better way of approaching intersystem aggregation issues).

42 Judicial Federalism, supra note 7, at 1532. Schwarzer had previously authored an article 35 discussing the benefits of informal ad hoc coordination between state and federal judges in overlapping litigation, promoting its continuation. See William W. Schwarzer, Nancy E. Weiss, \& Alan Hirsch, Judicial Federalism in Action: Coordination of Litigation in State and Federal Courts, 78 VA. L. Rev. 1689, 1700-30 (1992). As his later proposal makes clear, however, he has come to believe that such coordination may not do enough to reduce inefficiencies, especially when many judges are involved. Judicial Federalism, supra note 7, at 1532. 
removal of related state-court actions to the federal MDL court for coordinated 1 discovery proceedings. ${ }^{43}$

Proposals in this first group have been met with concerns about the implications of altering the state-federal jurisdictional structure. Responding to Schwarzer's proposal, for instance, Judge Sam Pointer, Jr., who oversaw the In 5 re Silicone Gel Breast Implants MDL, ${ }^{44}$ has expressed concern that removing parallel state cases to the federal MDL court would impair the ability of the MDL judge to manage discovery effectively (as discovery management is frequently interrelated with the management and resolution of substantive issues in the litigation). ${ }^{45}$ Further, Judge Pointer also noted that, even if such removal 10 were permitted, the time state cases spend in federal court should be limited, given the fear by plaintiffs that removal would mean their cases were lost forever to distant federal proceedings. ${ }^{46}$ Along similar lines, former Chairman of the JPML, William Terrell Hodges, commented in a 2004 interview that state claims that overlapped with federal cases in MDL presented a "challenging issue," but 15 that the panel was wary of "open[ing] the floodgates to an onslaught of litigation in the federal courts that would overwhelm [the panel] ... or encroach upon traditional jurisdiction of the states."47

The second group of responses to the non-removability of state actions to federal MDL stops short of proposing to change the federal-court jurisdictional 20 structure or current MDL procedures and instead suggest increased informal coordination between federal and state judges. These reforms posit that such cooperation helps reduce duplicative proceedings, ${ }^{48}$ and the FJC, the JPML, and

43 Judicial Federalism, supra note 7, at 1565-66.

44 See In re Silicone Gel Breast Implants Prods. Liab. Litig., 793 F. Supp. 1098, 1099-100 (J.P.M. L. 1992) (naming Judge Pointer as the transferee judge for the MDL).

45 Sam C. Pointer, Jr., Reflections by a Federal Judge: A Comment on Judicial Federalism: A Proposal to Amend the Multidistrict Litigation Statute, 73 TEx. L. REv. 1569, 1570 (1995).

46 Id. at 1570.

47 Gregory Hansel, Extreme Litigation: An Interview with Judge Wm. Terrell Hodges, Chairman of the Judicial Panel on Multidistrict Litigation, 19 ME. B.J. 16, 20 (2004).

48 See Borden \& Lee III, supra note 8, at 1015, 1020-21 (discussing coordination efforts and analyzing the results of an FJC study that found that of federal judges who were aware of parallel state proceedings, nearly $60 \%$ communicated either directly or indirectly with state counterparts); Jerome I. Braun, The Second Time's a Charm: Taking a Fresh Look at Judge 35 Schwarzer's Proposal for Discovery Coordination in Large-Scale Multi-Forum Litigation, 226 F.R.D. 46, 51 (2005); McGovern, Toward a Cooperative Strategy, supra note 8, at 1882-96 (outlining cooperative case management strategies for federal and state judges in mass tort litigation); McGovern, Rethinking Cooperation, supra note 8, at 1853-70 (discussing cooperative procedures in various mass torts cases and suggesting normative guidelines for future coordination efforts); James E. Mies, A Comment on "Judicial Federalism In Action,” 78 VA. L. Rev. 1763, 40 
the Conference of Chief Justices all have explicitly encouraged such cooperation. ${ }^{49} 1$ In contrast with the more formalized and drastic procedural reforms suggested above, none of which have been enacted, according to a recent FJC study, 89\% of transferee judges who were aware of parallel state proceedings attempted to cooperate and coordinate with their state counterparts in various ways, most 5 frequently by establishing common document depositories for discovery or by scheduling coordinated hearings on dispositive motions, trial dates, and Daubert or Frye hearings. ${ }^{50}$

One prominent example of attempts at such coordination comes, not surprisingly, from Judge Weinstein, who reached out via court order to state judges 10 overseeing cases related to In re: Zyprexa Products Liability Litigation, ${ }^{51}$ providing those judges with updates about the status and progression of the cases before him in the MDL proceedings, and asking those judges to engage in a number of specific forms of coordination efforts. Critics of informal, bottom-up coordination efforts argue, however, that such measures do not go 15 far enough. In particular, critics point out that these informal measures can only achieve a limited degree of coordination, and that the level of coordination achievable, and correspondingly, the efficiency gains achievable, declines as

1764-67 (1992) (highlighting certain issues discussed in Schwarzer's article from the perspective of a state judge); Schwarzer et al., supra note 42, at 1700-30 (discussing various examples of judges' efforts to coordinate the proceedings in mass tort cases); see also Pointer, Jr., supra note 45, at 1569-71 (discussing federal-state cooperation in MDL 962 and identifying possible limitations on strategies seeking to remove parallel state cases); Jack B. Weinstein, Ethical 25 Dilemmas in Mass Tort Litigation, 88 Nw. U. L. Rev. 469, 479 (1994) (discussing Judge Sam Pointer's aggressive management of the breast implant litigation).

49 In 2009, the FJC and the JPML jointly published a pamphlet advising transferee judges on best practices in case management; one step is to "Coordinate with Parallel State Court Cases." See JPML \& FCJ, "Ten Steps to Better Case Management: A Guide for Multidistrict Litigation Transferee Judges,” 7 (2009), available at http://www.fjc.gov/public/pdf.nsf/lookup/mdlguide. 30 pdf/\$file/mdlguide.pdf. Additionally, in a more recent jointly published pocket guide for case management of products liability cases, the FJC and the JPML included a lengthy section on inter-jurisdictional communication. See Barbara J. Rothstein \& Catherine R. Borden, FJC \& JPML, Managing Multidistrict Litigation in Products Liability Cases: A Pocket Guide for Transferee Judges (2011), available at http://www.fjc.gov/public/pdf.nsf/lookup/MDLGdePL.pdf/\$file/MDLGdePL. pdf. Finally, in January 2011, the Conference of Chief Justices adopted a resolution "Directing 35 the National Center for State Courts to Promote Communication and Best Practices for the Management of Like-Kind Litigation That Spans Multiple Jurisdictions and Federal Districts." Conference of Chief Justices, Resolution 2, in "Policy Statements \& Resolutions," available at http://ccj.ncsc.dui.us/MultiJurisResolution/resol2District.html/.

50 Borden \& Lee III, supra note 8, at 1020-21.

51 In re Zyprexa Prods. Liab. Litig., 2004 WL 3520248 (E.D.N.Y. Aug. 18, 2004). 
the number of judges involved increases and choice of law issues become more 1 complex. $^{52}$

\section{B Legislative responses to overlapping state and federal cases in MDL}

Congress, too, has taken some steps to remedy the inefficiencies associated with overlapping state and federal cases in mass litigation, though such efforts have been fewer, and certainly less comprehensive in scope, than some scholars predicted as mass litigation became a more prominent feature of the U.S. 10 litigation landscape. ${ }^{53}$ Indeed, across the broad spectrum of mass litigation, the basic federalism-based jurisdictional structure remains largely intact. Nonetheless, Congress has not been completely inattentive to the inefficiencies of unconsolidated, uncoordinated cases in mass litigation.

For starters, in 2002, Congress enacted the Multiparty, Multiforum Trial 15 Jurisdiction Act ("MMTJA"), ${ }^{54}$ which expanded the jurisdiction of federal courts over certain mass tort cases. Specifically, the MMTJA added 28 U.S.C. § 1369, which gives federal district courts original jurisdiction over civil actions in which parties are minimally diverse, in which at least 75 deaths that arise from a single accident in a discrete location are involved, and in which at least one of three 20 enumerated additional conditions are met, ${ }^{55}$ subject to the limitation that district courts must abstain from exercising this jurisdiction if a substantial majority of all plaintiffs, as well as the primary defendants, are citizens of a single state and the claims asserted will be governed primarily by the laws of that state. ${ }^{56}$ The MMTJA also amended the federal removal statute to provide for removal juris- 25 diction over (1) actions that could have been brought in district court under $\S$ 1369 and (2) all state-court actions arising from the same accident in situations

52 Judicial Federalism, supra note 7, at 532.

53 See, e.g., Linda S. Mullenix, Complex Litigation Reform and Article III Jurisdiction, 59 FoRDHAM 30 L. Rev. 169, 170-71 (1990) ("There can be little doubt that within the next decade Congress will enact legislation modifying, amending, or completely revamping the procedures governing multiparty, multiforum cases.”).

54 Pub. L. 107-273, Div. C, Title I, § 11020(b)(1)(A), 116 Stat. 1826 (codified at 28 U.S.C. § 1369). 55 See 28 U.S.C. $\S 1369$ (a). Those additional conditions require that either (1) a defendant resides in a state and a substantial part of the accident took place in another state or location, 35 (2) any two defendants reside in different states, or (3) substantial parts of the accident took place in different states. 28 U.S.C. § 1369(a)(1)-(3). It is worth noting that the first condition will be met even if the defendant is also a resident of the state where a substantial part of the accident took place, and the second condition will be met even where the defendants are also residents of the same state or states. $I d$. 
where the defendant is already a defendant in another case that was or could 1 have been brought under $\S 1369 .^{57}$

On its own terms, the MMTJA is by no means a comprehensive response to the existence of non-removable state cases that overlap with federal MDL cases of the sort envisioned by Redish and Schwarzer. It deals only with the relatively 5 small subset of overlapping lawsuits filed in various state and federal jurisdictions after a single disaster. ${ }^{58}$ Moreover, courts have interpreted the MMTJA's scope quite narrowly. For instance, courts have parsed the statutory language to construe "accident" to exclude natural disasters. ${ }^{59}$ In a prominent line

57 See 28 U.S.C. $\S 1441(\mathrm{e})(1)(\mathrm{B})$. Notably, section 1441(e)(1)(B) departs from the traditional removal rule, which is codified in section 1441(e)(1)(A) and allows removal of a state claim if it "could have been brought [in federal court] under section 1369." See id. Under section 1441(e) (1)(B), a defendant can remove an action even if it could not have been brought in federal court as an original matter. See id.; see also Stephen Aslett, Wallace v. Louisiana Citizens Property Ins. Corp.: The Fifth Circuit Expands Federal Jurisdiction Over State Court Class Actions Arising Out of Hurricane Katrina, 81 Tul. L. Rev. 1331 (2007).

58 See Passa v. Derderian, 308 F. Supp. 2d 43, 52 (D.R.I. 2004) (stating that in drafting the MMTJA, Congress "concentrated 'on the problem of dispersed complex litigation arising out of a single accident resulting in multiple deaths or injuries." (quoting H.R. Conf. Rep. No. 107-685 at 199 (2002))); see also Wallace v. Louisiana Citizens Property Ins. Corp., 444 F.3d 697, 702 (5th Cir. 2006) ("[T]he MMTJA was designed to ameliorate the restrictions on the exercise of federal jurisdiction that ultimately forced parties in multiple suits arising from the same disaster to litigate in several fora.” (citing H.R. Rep. No. 106-276 at 7 (1999))); Case v. ANPAC Louisiana Ins. Co., 466 F. Supp. 2d 781, 785 (E.D. La. 2006) ("Section 1369 ... [is] meant to foster judicial economy in the resolution of actions involving certain mass disasters by circumventing conventional limitations on federal subject matter jurisdiction.").

59 Because the statutory definition of the term "accident" distinguishes between a "sudden accident," and a "natural event culminating in an accident," see 28 U.S.C. § 1369(c)(4), district courts have reasoned that a natural event could not, by itself, constitute the requisite single accident. See, e.g., Racca v. Louisiana Farm Bureau Mut. Ins. Co., 2006 WL 3905004, *2 (E.D. La. Dec. 8, 2006) (“[A] natural event cannot constitute a 'sudden accident' because the MMTJA's definition goes on to define 'accident' as also a 'natural event culminating in an accident.'... 30 Clearly a hurricane is a natural event.” (citing 28 U.S.C. § 1369(c)(4))). Courts also frequently contrasted natural disasters with examples of the type of sudden, isolated, disaster contemplated by Congress in the MMTJA's legislative record such as "hotel fire[s]," "railroad, airplane or bus accident[s]," and "bridge collapse[s]." Case v. ANPAC Louisiana Ins. Co., 466 F. Supp. 2d 781, 792 (E.D. La. 2006); id. ("The multi-day development of the storm and ubiquitous warnings of its approach in the days before its landfall contrast sharply with the types of mass accidents contemplated by Congress when it enacted the MMTJA, namely plane crashes, train wrecks, hotel fires, and environmental spills.” (citing 147 Cong. Rec. H893-01 (2001); 137 Cong. Rec. E1923-02 (1991)). Indeed, even litigants that attempted to adapt to these holdings by claiming that the levee breaches were the requisite "accident[s]" in which the hurricane culminated were largely unsuccessful in obtaining removal under the statute. See Robin J. Effron, DisasterSpecific Mechanisms for Consolidation, 82 Tul. L. Rev. 2423, 2439-40 (2008) ("When the 40 
of decisions, the Eastern District of Louisiana rejected the argument, in 1 the Hurricane Katrina litigation, that a hurricane could constitute an "accident" under the MMTJA. ${ }^{60}$ Courts have also held that the burden of demonstrating the existence of at least 75 deaths rests with the party seeking removal under the MMTJA. ${ }^{61}$ Finally, regarding the MMTJA's abstention provision-subsection (b) of 5 28 U.S.C. § 1369-courts have found that "all plaintiffs" must include all potential plaintiffs, (or all those who died or suffered injury as a result of the accident) and that a "substantial majority" must be a figure in excess of $50 \%$. $^{62}$

In addition to the MMTJA, Congress has acknowledged the inefficiencies associated with complex litigation involving various plaintiffs in the Civil Justice 10 Reform Act of $1990,{ }^{63}$ which instructs courts to develop expense and delay reduction plans following certain case management principles. ${ }^{64}$ The Act also requires that the Judicial Conference prepare semi-annual reports detailing the

argument that the Hurricane would be the triggering event for the MMTJA failed to gain traction in the district courts, litigants attempted to narrow the scope by pointing to the levee breaches as the requisite accident." Ultimately, this strategy "has also failed to form the basis of MMTJA jurisdiction."). They often failed because they could not demonstrate that the plaintiffs' actions arose out of a single levee breach, though some courts noted that removal might be proper if they could. See, e.g., Carroll v. Lafayette Ins. Co., 2006 WL 2663013, at *3 (E.D. La. Sept. 14, 2006) (holding that because there were multiple levee breaches at several locations the deaths did not occur at a discrete location); Case v. ANPAC La. Ins. Co., 466 F. Supp. 2d 781, 794 (E.D. La. 2006) (stating that "[i]nterpreting the term 'single accident' so broadly as providing for multiple levee breaches does not coincide with the purposes of the MMTJA").

60 See, e.g., Ho v. Colony Ins. Co., 2008 WL 145023, *3 (E.D. La. Jan. 14, 2008) (“Courts in ... [the Eastern District] ... 'have consistently found that Hurricane Katrina does not constitute an accident for purposes of $\S 1369$ analysis”' (quoting Roby v. State Farm Fire \& Cas. Co., 464 F. Supp. 2d 572, 576 (E.D. La. 2006))); Flint v. Louisiana Farm Bureau Mut. Ins. Co., 2006 WL $2375593,{ }^{\star} 3$ (E.D. La. Oct. 25, 2006) (declining to "interpret the statutory definition of 'accident' so broadly" as to classify Hurricane Katrina as an accident); see also Karnezis, supra note 55, § 930 (collecting cases within the Fifth Circuit holding that a "hurricane is not an 'accident' within the meaning of the" MMTJA); Effron, supra note 59, at 2437-38 ("District court judges interpreting the [MMTJA] in the context of the Hurricane Katrina litigation have consistently held that Hurricane Katrina is not an accident within the meaning of the statute.”); Joshua A. Decuir, Note, A Federal Tete-a-Tete? The Multiparty, Multiforum Trial Jurisdiction Act and Hurricane Katrina: Past, Present, and Future Considerations, 68 LA. L. Rev. 681, 696 ("[T]he judges of the Eastern District of Louisiana appear to have concluded that for purposes of MMTJA jurisdiction, Hurricane Katrina itself does not suffice as the required 'single accident."').

61 See Case v. ANPAC Louisiana Ins. Co., supra note 58.

62 See Passa v. Derderian, supra note 58.

63 Pub. L. 101-650, 104 Stat. 5089, 136 Cong. Rec. H8263-66 (codified at 28 U.S.C. §§ 471-82). 64 See 28 U.S.C. $\S 473$. 
statistics of decisions made by the federal judiciary. ${ }^{65}$ Though it is not directly 1 focused on the issue of overlapping state claims, the Act does suggest "systematic, differential treatment of civil cases" tailored to "case complexity, the amount of time reasonably needed to prepare the case for trial, and the judicial and other resources required and available for the preparation and disposition of the 5 case," 66 and such differential treatment could include coordination by the federal courts with their state counterparts to help reduce duplicitous proceedings or engage in other cost-saving procedures.

Congress's most recent and ambitious foray into the revision of the federal-state jurisdictional structure is the 2005 Class Action Fairness Act ("CAFA"), which sig- 10 nificantly expanded federal removal jurisdiction over state-court class actions. ${ }^{67}$ In enacting CAFA, Congress was motivated by the goal of bringing more class actionsoften those involving issues of national significance-out of state court and into federal court. ${ }^{68}$ Although CAFA has the effect of facilitating greater consolidation of state-court class actions into federal MDL, it is almost certainly incorrect to say that, 15 in enacting it, Congress was concerned primarily with the inefficiencies of duplicative litigation in state and federal court. ${ }^{69}$ As the legislative history indicates, Congress was largely concerned that a few aberrant state judges were certifying class actions that few other judges would certify, thereby enabling plaintiffs to extract settlements based upon unmeritorious claims. ${ }^{70}$ By allowing for the removal 20 of more putative class actions to federal court, some in Congress believed that these cases would not be certified as class actions, and thus disappear altogether. ${ }^{71}$

65 See 28 U.S.C. §§ 476, 479; see also Lauren Robel, Fractured Procedure: The Civil Justice Reform Act of 1990, 46 Stan. L. Rev. 1447 (1994); Jeffrey J. Peck, “Users United”: The Civil Justice Reform Act of 1990, 54 LaW \& Contemp. Probs. 105 (1991).

66 See 28 U.S.C. $\S 473$.

67 See 28 U.S.C. § $1332(\mathrm{~d}), \S 1453$.

68 See Edward A. Purcell, Jr., The Class Action Fairness Act in Perspective: The Old and the New in Federal Jurisdictional Reform, 156 U. PA. L. Rev. 1823, 1851-88 (2008).

69 See id. at 1855.

70 Congress feared "state court provincialism against out-of-state-defendants" and "judicial failure to recognize the interests of other states" in nationwide class actions brought in state courts. S. Rep. 109-14, at 5-6; see also Stephen B. Burbank, The Class Action Fairness Act of 2005 in Historical Perspective: A Preliminary View, 156 U. PA. L. Rev. 1439, 1500 (2008) (discussing how plaintiffs' lawyers turned increasingly to some state courts that were friendlier to class actions and willing to apply their choice-of-law rules in such a way as to facilitate the application of a single state's law to every class member).

71 Purcell, Jr., supra note 68, at 1864. As an empirical matter, the federal courts have not so far proven as hostile to class certification as some members of Congress may have envisioned, though that may change as strict interpretations of Rule 23 continue to emanate from the Supreme Court. See Comcast Corp. v. Behrend, 133 S. Ct. 1426, 1434-35 (2013) (holding that 40 
CAFA's alteration of the diversity statute was, as the title of the Act suggests, 1 largely limited to cases that constituted class actions as defined in Fed. R. Civ. P. 23. ${ }^{72}$ However, the lesser-known "mass action" provisions of the Class Action Fairness Act, which have only begun to receive attention in the scholarly literature $^{73}$ and in the courts ${ }^{74}$ may expand CAFA's scope to include removal 5 of other state-court cases, not part of a certified class action, into federal court, though it seems unlikely that the mass action provision will have much of an impact on the non-removable state cases in MDL. CAFA defines a mass action as any civil action other than a traditional class action "in which monetary relief claims of 100 or more persons are proposed to be tried jointly on the ground that 10 the plaintiffs' claims involve questions of law or fact...."75 CAFA then specifies that a "mass action" "shall be deemed to be a class action removable under [§1332(d)(2)-(10)] ... if it otherwise meets the provisions [in §1332(d)(2)-(10)].”76

Courts have struggled with the question of whether state-court actions are considered "mass actions" for purposes of removal under CAFA, ${ }^{77}$ but however 15

the Third Circuit improperly certified a class of customers alleging antitrust violations by a cable television provider when it did not first determine that the class's proposed damages model could show damages on a classwide basis); Wal-Mart Stores, Inc. v. Dukes, 131 S. Ct. 2541, 255052 (2011) (holding that commonality under Rule 23 requires more than the identification of a single common question of law or fact in a class and is only satisfied by claims that "depend 20 upon a common contention ... of such a nature that it is capable of classwide resolution").

72 See 28 U.S.C. § 1332(d)(1)(B).

73 See, e.g., Linda S. Mullenix, Class Actions Shrugged, Rev. Litig. at 2 n. 5 (forthcoming 2013), available at http://ssrn.com/abstract $=2211843$ (collecting limited scholarship on CAFA's mass action provisions).

74 In January 2014, the Supreme Court addressed the mass action provisions for the first time in when it decided Mississippi ex rel. Hood v. AU Optronics Corp., 134 S.Ct. 736 (2014). See infra n. 77.

7528 U.S.C. $\$ 1332(\mathrm{~d})(11)(\mathrm{B})(\mathrm{i})$.

76 See 28 U.S.C. § 1332(d)(11)(A).

77 Initially, courts have had trouble implementing CAFA's requirement that a mass action 30 involve 100 plaintiffs proposed to be tried jointly under 28 U.S.C. $\S 1332(d)(11)(B)(i)$. First, CAFA does not specify the point in litigation at which a court should evaluate the number of persons whose cases have been "proposed" to be tried jointly. The Seventh Circuit has advised, however, that the question "is not whether 100 or more plaintiffs answer a roll call in court" and that the determination of the 100 plaintiff requirement does not have to await, or even require, a trial plan for the claims of the 100 or more persons. See Bullard v. Burlington N. Santa 35 Fe Ry. Co., 535 F.3d 759, 772 (7th Cir. 2008) (Easterbrook, C.J.). Instead, that determination occurs at the time of removal. Id. Second, it is also not always clear what constitutes a "proposal" for joint trial, and the Seventh Circuit has even suggested that in absence of a specific request for a joint trial plan, a plaintiff's complaint, request for transfer and consolidation, or other litigation actions may implicitly propose one, rendering a lawsuit a mass action. See In re Abbot Labs., Inc., 698 F.3d 568 (7th Cir. 2012). Other courts seem to have rejected the notion of an "implicit" joint trial plan. See, e.g., Romo v. Teva Pharmaceuticals, 731 F.3d 918 (9th Cir. 2013) (concluding that a joint trial plan was not proposed when plaintiffs had only moved for coordination and did not specifically mention an intent to coordinate through trial). 
these debates are resolved, it is clear that the mass action provision cannot 1 achieve anywhere close to across-the-board removal of state cases that overlap with federal MDL proceedings to the federal MDL court. Indeed, Congress provided explicitly that a mass action removed to federal court pursuant to CAFA shall not be consolidated as part of an MDL unless "a majority of the 5 plaintiffs in the action request transfer pursuant to section 1407."78 Moreover, the statute explicitly excludes from the definition of a "mass action" "claims that have been consolidated or coordinated solely for pretrial proceedings."79 To the extent, then, that such cases might have appeared to constitute a convenient, well-packaged unit for removal to federal court, and then coordination through 10 the federal MDL process, Congress has all but foreclosed the use of CAFA to achieve that result.

Furthermore, courts have also struggled with CAFA's stipulation that in order to be removable, mass actions must satisfy the amount in controversy requirements of section 1332(a), as well as section 1332(d)(2)-(10). The interplay of these subsections has caused the Eleventh Circuit to refer to the mass action provisions as an "opaque, baroque maze of interlocking cross-references that defy easy interpretation.” Lowery v. Alabama Power Co., 483 F.3d 1184, 1198 (11th Cir. 2007). Here, the major difficulty concerns the presence within a mass action of individual claims below the $\$ 75,000$ amount in controversy threshold. The definition of a mass action makes it clear that there is no jurisdiction over such individual claims, see 28 U.S.C. $\S$ 1332(d)(11)(B)(i), but the question is whether they should render jurisdiction over the entire mass action problematic. Finding that strictly requiring that each action within a mass action satisfied the individual amount in controversy threshold would render the $\$ 5$ million aggregate amount in controversy requirement "mere surplusage," the Eleventh Circuit was the first to state the leading interpretation of these provisions. See Lowery, 483 F.3d at 1205. It found that if a mass action met the aggregate $\$ 5$ million threshold, it was eligible for removal, at which point the district court had to remand individual claims under $\$ 75,000$ but could retain jurisdiction over the remaining cases even if they fell below 100 in number or $\$ 5$ million in the aggregate. See id.; see also William B. Rubenstein, Mass actions under CAFA, in 2 Newberg on Class Actions $\S 30$ 6:24 (5th ed.) (discussing this developing rule).

Finally, the Supreme Court recently clarified the mass action provisions' exception for suits in which "all of the claims ... are asserted on behalf of the general public," 28 U.S.C. § 1332(d)(11) (B)(ii)(III), and its applicability to parens patriae suits brought by state attorneys general. See Mississippi ex rel. Hood v. AU Optronics Corp.. 134 S.Ct. 736 (2014). Specifically, the Court held that such suits are not remo-vable under CAFA's mass action provision when the state is the sole 35 plaintiff, the claims arise under state law, and the state attorney general possesses statutory and common law authority to assert all of the claims in the suit. Id.; 28 U.S.C. § 1332(d)(11)(C) (i).

7928 U.S.C. § 1332(d)(11)(B)(ii)(IV). 


\section{Part III: the promise of non-removable state actions in MDL}

The reforms described above all reflect a fairly uniform concern-that the federal characteristics of our judicial system create serious inefficiencies in the resolution of mass litigation. ${ }^{80}$ As understandable as that concern is, I am not fully 5 convinced that jurisdictional efforts at further consolidation of parallel statecourt cases, or even informal arrangements that aim for as much inter-system coordination of pre-trial activity as possible are necessarily the best way forward. There are a number of reasons for this hesitation, and too many to explore in-depth in a single piece. However, I mention two here in service of broadening 10 the debate and with the recognition that we have both an opportunity and a monumental challenge in designing the mechanisms of mass litigation resolution to achieve some of the unfulfilled promise of the class action device in what might well be the post-class action era.

First, and very briefly, the reform proposals in Part II are grounded primarily 15 in efficiency concerns about the duplicative litigation brought about by parallel state and federal cases in mass litigation. These concerns will no doubt continue to be part of the debate (and will no doubt hold sway, as they should to some extent). As a preliminary matter, it is far from certain, however, whether reforms that provide for greater consolidation of state-court cases in MDL would, in fact, 20

80 Indeed, recent scholarly proposals, like Redish's and Schwarzer's, as well as legislative reforms like Congress's enactment of the MMTJA, can be situated among other proposals for reducing inefficiencies in the mass litigation universe. As far back as 1990, Linda Mullenix traced a number of attempts and proposals to ameliorate the inefficiencies associated with complex litigation-including those associated with overlapping state and federal claims. See Linda S. Mullenix, Complex Litigation Reform and Article III Jurisdiction, 59 FORDHAM L. Rev. 169 (1990). Perhaps unsurprisingly, many of the proposals for reforming complex litigation at that time involved expanding or modifying the scope of federal jurisdiction. In particular, Mullenix focused on proposals from the American Bar Association and the American Law Institute, as well as on a predecessor of the MMTJA, see Mullenix, supra note 80, at 222-23, and discussed the constitutionality of such proposals under U.S. Const. Art. III. Id.; see also ABA Commission on Mass Torts, Report Number 126 to the ABA House of Delegates (1989); Am. L. Inst., ALI Complex Litigation Project Council Draft No. 2 (1989); Multiparty, Multiforum Jurisdiction Act of 1990, H.R. 3406, 101st Cong., 2d Sess., 136 Cong. Rec. H3116-19. From Mullenix’s perspective, expansion of federal jurisdiction along these lines, and by extension along the lines that both Redish and 35 Schwarzer suggested in more recent years, is constitutionally impermissible. Mullenix, supra note 80 , at 222-23. Alternatively, such inefficiencies could (and perhaps must, according to Mullenix) be cured, if at all, through the passage of substantive federal law for mass litigation. Id. at 224 ("Federalizing the substantive law governing complex cases will assure valid federal jurisdiction over complex litigation. This will not occur, however, because it is politically unacceptable to enact a federal tort law or a federal products-liability law.”). 
even achieve greater efficiency. ${ }^{81}$ Putting that aside, though, while efficiency is a 1 compelling functional reason to explore alternatives to our current system of federalism and its relationship to mass litigation, perhaps a sounder theoretical grounding for reforms like CAFA lies in the notion that cases involving claims against entities operating in national markets and that have allegedly caused 5 nationwide harm ought to proceed in, and be resolved by, federal courts. ${ }^{82}$ In other words, they ought to proceed in a federal forum that is commensurate to the relevant harm in jurisdictional scope and authority.

On that score, the foregoing reform proposals could only advance that goal incompletely and by way of indirection. Whether procedural consolidation is 10 achieved by removal via CAFA (or a broadened version thereof), by amendment to the MDL statute, or by some parallel-court-issued injunction or parallel-courtabstention, the solution is indirect and incomplete so long as the substantive

81 See, e.g., Hansel, supra note 47, at 20 (recounting some of the concerns of a former chairman of the JPML regarding the expansion of federal jurisdiction to include more overlapping state cases in MDL); see also DeLaventura v. Columbia Acorn Trust, 417 F. Supp. 2d 147, 149 (D. Mass. 2006) ("[A]s compared to the processing time of an average case, MDL practice is slow, very slow.”); Adrienne Bramlett Kvello, The Best of Times and the Worst of Times: How Borg-Warner and Bankruptcy Trusts are Changing Asbestos Settlements in Texas, 40 THE Advoc. 80, 81 (2007) (discussing how many asbestos claims were "relegated" to the "purgatory of the MDL inactive docket" effectively "signal[ing] the demise of asbestos litigation"); Benjamin W. Larson, Lexecon Inc. v. Milberg Weiss Bershad Hynes \& Lerach: Respecting the Plaintiff's Choice of Forum, 74 Notre Dame L. Rev. 1337, 1365 (1999) (The purported "efficiency gains of consolidated trial are not supported by reality."); Mark Hermann, To MDL or Not to MDL? A Defense Perspective, 24 LiTIG. 43, 46 (1998) (discussing how MDL proceedings can serve as a delaying 25 tactic used by defendants that consumes significant amounts of time and often results in depriving plaintiffs of control over the schedule of the litigation of their individual claims); Desmond T. Barry Jr., A Practical Guide to the Ins and Outs of Multidistrict Litigation, 64 Def. Couns. J. 58, 58 (1997) (noting that for MDL procedures to be effective, they require "strong and creative action from transferee judges" and concluding that "[u]ltimately, it is the resourcefulness of the court and counsel which will determine how efficiently, economically, and fairly 30 mass tort litigation is brought to a conclusion")

82 See Suzanna Sherry, Overruling Erie: Nationwide Class Actions and National Common Law, 156 U. PA. L. Rev. 2135, 2139-42 (2008) (arguing that CAFA should be read as overruling Erie Railroad Co. v. Tompkins, at least for the national-market cases that it places within federal court jurisdiction); Samuel Issacharoff \& Catherine M. Sharkey, Backdoor Federalization, 53 UCLA L. Rev. 1353, 1414 (2006) (arguing that federalism concerns with the creation of national 35 laws governing national disputes "appear secondary to the need to provide an effective forum for claims under national law”); see also Robert D. Cooter \& Neil S. Siegel, Collective Action Federalism: A General Theory of Article I, Section 8, 63 STAN. L. Rev. 115 (2010) (suggesting that the real limit regarding federal regulatory power should exist between matters that would entail collective action problems if left to the states and those that the states can properly regulate individually). 
law governing the nationwide problem is decidedly non-national. For this rea- 1 son, scholars have insisted on the need for nationwide products liability laws and other tort laws when defendants operate within a national market and harm occurs on a national scale. ${ }^{83}$ Similarly, some have advocated a revision (or even complete overhaul) of the Erie doctrine that would permit a federal court to 5 impose, or even create, its own common law on the particular issue at hand. ${ }^{84}$ The debates over such proposals are robust, ongoing, and deserve far more attention in relationship to the issue of parallel state and federal cases than I can give them here. ${ }^{85}$ Suffice to say, however, that as long as the substantive laws of the various states continue to govern individual lawsuits in the context of mass 10 litigation (as they will for the foreseeable future), they will pose a serious impediment to the goal of achieving efficient and rational resolution of mass litigation through greater procedural consolidation and coordination. In any event, eliminating the parallel cases through consolidation, and thus removing the possibility of harnessing already-available mechanisms-the state cases 15 themselves-to facilitate fair, accurate, and legitimate mass litigation governance through settlement, raises additional concerns.

In particular, the second concern I have, and one upon which I focus primarily here, pertains to the relationship between federalism and mass litigation governance through settlement. In the world of complex litigation, 20 global settlements have been characterized by scholars as more closely resembling administrative regulation, or public governance, than run-of-the-mill

83 Suzanna Sherry has suggested as much. See Sherry, supra note 82.

84 See, e.g., id. at 2139-42; Issacharoff \& Sharey, supra note 82, at 1414-31; see also Elizabeth J. Cabraser, Just Choose: The Jurisprudential Necessity to Select a Single Governing Law for Mass Claims Arising from Nationally Marketed Consumer Goods and Services, 14 Roger WiLliams U. L. REv. 29, 30-32 (2009) (advocating the adoption of a single governing body of law across claims subject to different state laws in class actions and other aggregate litigation-particularly those which involve variations in law rather than true conflicts).

85 To be clear, I am not taking a position here on the possible need for federal tort law or for federal regulation of manufacturers whose products may lead to tort liability on a national scale. To do so would require, at the very least, descriptive exploration of, and concomitant normative judgments about, the extent to which a defendants' obligations under varying state laws actually rise to a level of inconsistency that is damaging to the functioning of a particular interstate market, the related issue of the extent to which a given state's heightened "protection" of its citizens results in heightened burdens to defendants while incentivizing out-of-state plaintiffs to free-ride the protections of the aberrant state, and the extent to which the removal of such protection, even if it incentivizes free-riding, would simply create an undesirable race to the bottom on issues like product safety. Along those lines, a condition precedent to the introduction of broad-sweeping national tort law might well be the development of a theory of mass litigation federalism, a project I leave for future work. 
private-claim resolution mechanisms. ${ }^{86}$ Such settlements seek to effectuate glo- 1 bal peace through the compensation of numerous plaintiffs (even sometimes plaintiffs not yet known or in existence), whose related claims typically stem from harm that had widespread reach, frequently threaten a defendant or set of defendants with substantial liability, and stand poised to have a significant 5 impact on national markets. In short, in these and in other ways, courts tasked with managing and resolving a multiplicity of claims are being asked, along with private attorneys, to engage not so much in private dispute resolution as in private regulation vis-à-vis issues of broad public concern. ${ }^{87}$

86 See, e.g., Richard A. Nagareda, Turning from Tort to Administration, 94 Mich. L. Rev. 899 (1995); Martha Minow, Judge for the Situation: Judge Jack Weinstein, Creator of Temporary Administrative Agencies, 97 Colum. L. Rev. 2010 (1997); NagaREDA, supra note 4, at viii ("The evolving response of the legal system to mass torts has been to shift from tort to administration.”).

87 Much of the work on mass tort settlements as resembling forms of public regulatory governance was done by Richard Nagareda, who evaluated most closely the sorts of settlement grids that emerged in response to class action litigation. It is worth noting that one important component of Nagareda's theory about mass settlements as resembling public regulation is the notion that these settlements frequently purported to resolve the claims of people not even yet injured-future claimants-and from that perspective, litigation looked like more classic forms of prospective governance than backwardlooking litigation. Nagareda, supra note 86, at 940 (arguing that "the shift [in emphasis] from retrospective enforcement to prospective specification of conduct [in administrative agencies] parallels the shift in the recent mass tort settlements from retrospective adjudication of individual tort claims to the development of prospective compensation regimes for future claimants"); see also Minow, supra note 86, at 2014 ("Especially in complex tort cases, Judge Weinstein has repeatedly structured suits as efforts to achieve 'total peace,' and therefore approved plans to include potential future claims."); NAGAREDA, supra note 4, at 57 ("This prospective dimension-the power to set the legal rules that shall govern the future and to make those rules binding-is what sets apart private administration in the sense used here from aggregate settlements of ongoing litigation.”). While settlement grids devised in mass litigation outside of the confines of the class action may attempt to deal with future claims, depending on the particulars of the mass litigation, such a condition is not central to my point here. Whether future claims are involved or not, resolving scores of claims related to a single harm or set of harms by a single defendant or set of defendants, on a national scale, affecting plaintiffs across the country, less resembles the classic approach of one-on-one (or few-onfew) litigation of the non-mass variety, and frequently far more resembles more classic sorts of administrative-like governance whereby the interests of many in relationship to issues of frequently national concern must be balanced, considered, and ultimately resolved through a "grand compromise," viz. a settlement grid. This is particularly true given that, to reach some sort of resolution of 35 claims in mass litigation, it is not only impossible, as a matter of efficiency, judicial resources, and party resources to adjudicate each and every case in the mass litigation individually, but also is not ideal (for many of the same reasons) or likely necessary for determining the ultimate range of settlement values and eligibility for compensation available to all plaintiffs involved. To achieve global compromise, plaintiffs are necessarily treated as a group or as sub-groups within a larger set for purposes of determining, for instance, compensation eligibility and compensation amount. 
That insight has countless implications for mass litigation; here, I focus on 1 some of the possible implications of that conception of mass litigation for consideration of the role these non-removable cases could potentially play in improving the quality and legitimacy of mass litigation governance. The nonremovable nature of these state cases exists, because of federalism, but only 5 happenstantially. However, this non-removability perhaps makes them uniquely available and suited to aid in mass litigation governance, despite the fact that, whatever federalism's underlying purpose, it was of course not intended for the purpose of doing so. ${ }^{88}$ As Richard Nagareda recognized in his exploration of mass tort class actions, effective litigation governance requires the convergence, 10 in joint enterprise, of public institutions and private arrangements. ${ }^{89}$ In mass litigation, these private arrangements frequently take the form of settlement negotiations, and ultimately, comprehensive settlement grids. ${ }^{90}$ In Nagareda's view, good litigation governance requires public institutions both to empower and to discipline those private settlements. ${ }^{91}$ The sorts of reforms set forth in Part 15 II can be fairly characterized as attentive to the first of those two requirements: They set up the nature of the enterprise between the public institutions-the courts-and the private arrangements-the settlements-as one in which the former functions primarily to empower the latter. ${ }^{92}$

Mass litigation governance, however, also requires that resolution through 20 private settlement be disciplined by the public courts. It is the need for that discipline which reveals the potential promise that federalism might hold, however fortuitously, for mass litigation. In particular, the consequences of federalism in MDL-i.e., non-removable state cases-could be harnessed to discipline global settlements in mass litigation. More particularly, and in contrast with the 25 proposals discussed in Part II, this Part suggests that mass litigation may well benefit not so much from coordination and consolidation to eliminate the jurisdictional redundancy that results from these non-removable state cases, ${ }^{93}$

88 See, e.g., Cooter \& Siegel, supra note 82, at 135-56 (discussing many possible justifications for the federalist system of governance established by the U.S. Constitution).

89 NAGAREDA, supra note 4, at 101.

90 See, e.g., id. at 101.

91 Id. at 101.

92 To be sure, removing inefficient, duplicative, and, often perhaps, primarily strategic litigation 35 from the litigation landscape through consolidation or full-scale coordination could also constrain any resulting settlement insofar as it reduces the distortive impact of waste and gamesmanship on settlement values. However, any fortuitous disciplining effect would seem to be, at best, secondary. 93 I focus here on the non-removable state cases as a source of independent proceedings spread through different tribunals, given that they already exist as such. The notion of independent proceedings in various tribunals has been referred to as "jurisdictional redundancy." 40 
but rather from calculated and targeted harnessing of some sub-set of those non- 1 removable state cases to reap the values of those redundancies-an enterprise I will term, for now, "coordinated redundancy."

It is my argument here that some form of coordinated redundancy in mass litigation, which could be achieved by using some set of the already available 5 state cases as part of an overall endeavor to achieve global peace in any given mass dispute, could provide mechanisms for disciplining settlement grids in four key ways: one, by providing needed real-world data for use in any ultimate settlement grid; two, by ensuring greater legitimacy of those settlements as mechanisms of litigation governance; three, by potentially making any ultimate 10 settlements fairer to litigants; and four, by providing greater assurance that any resulting settlement terms will stick. To be clear, it is not the enterprise of this piece to undertake the separate project of setting forth the precise mechanicsincluding needed exploration regarding statistical sampling methods ${ }^{94}$ - of how such a regime would function in any given case. It is enough here to begin the 15 first exploration of the possibilities that these non-removable state cases may hold in advancing key values of mass litigation governance.

\section{A Real-world data}

First, as a descriptive matter, parallel state cases create an opportunity to obtain important real-world data needed for developing a market for the relevant claims and, relatedly, for disciplining the contours of an ultimate global settlement. ${ }^{95}$ These cases could generate more robust real-world data on the merits of 25 claims under relevant substantive law (which is often state law) ${ }^{96}$; on the relative strengths and weaknesses of the various legal claims; on how, and the

More specifically, the concept of jurisdictional redundancy-the notion that our system of federalism creates the possibility of vertical (federal-state) and horizontal (state-state) concur- 30 rency of litigation-was introduced and explored by Robert Cover. See Robert M. Cover, The Uses of Jurisdictional Redundancy: Interest Ideology, and Innovation, 22 WM. \& MARY L. REv. 639 (1981).

94 For an essay exploring the possibilities statistical sampling of cases holds for mass litigation, see Edward K. Cheng, When 10 Trials are Better than 1000: An Evidentiary Perspective on Trial Sampling, 160 U. PA. L. REv. 955 (2012).

95 The notion of real-world data as a mechanism for enabling claim maturation and for developing an ultimate plan for resolution in mass litigation derives from Judge Posner's recognition of the importance of a "decentralized process of multiple trials" for developing a market for claims. See In re Rhone-Poulenc Rorer, Inc., 51 F.3d 1293 (7th Cir. 1995) (Posner, J.). 96 For instance, one benefit of test cases in the early stages of a mass tort is to generate "maturation" of that tort. See, e.g., NAGAREDA, supra note 4, at 92. 
extent to which, those strengths and weaknesses vary under different states' 1 substantive laws; on the relative strengths and weaknesses of groups of claims that are distinguishable, perhaps (and perhaps likely) by various categories of factual predicates ${ }^{97}$; and on the relative weight appropriately attached to various pieces and forms of evidence. Here, I mean real-world in the very literal sense: 5 The non-removable state cases, used as test cases, would provide information about what actually happens when these cases are litigated in front of the relevant state judge and tried (where applicable) before a jury pooled from the relevant geographic area. ${ }^{98}$

For a number of reasons, this real-world data could potentially provide value 10 to mass litigation governance. First, and perhaps as part of an initial, coordinated set of decisions by all of the state judges and the MDL judge involved in a particular mass dispute, some of these state proceedings could be chosen for expedited treatment as independent-and and yes, to some quite purposeful degree, redundant-test cases for an overall settlement. Negotiations of mass 15 settlements can often be un- or under-informed by real-world data on claim values, and they can be vulnerable to being influenced by merits-independent sources of bargaining leverage, which can undermine the accuracy of the

97 In the class action context, the presence of such distinguishable groups of claimants, or differences between the claims of putative class members, often militates against class certification. See, e.g., Amchem Prods., Inc. v. Windsor, 521 U.S. 591, 624 (1997) (finding that differences between the claims of exposure-only plaintiffs did not share enough in common with the presently injured plaintiffs to satisfy Fed. R. Civ. P. 23(b)(3)'s predominance requirement); Gen. Telephone Co. v. Falcon, 457 U.S. 147, 159-61 (1982) (de-certifying a class for failure to satisfy FED. R. CIV. P. 23(a) as a result of differences between a group of claimants who had been hired and faced discrimination in terms of promotion and a group of claimants who had simply never been hired as a result of discrimination). These differences are most often a result of the extent and nature of the injuries suffered by various groups of claimants, as was the case in Amchem, 521 U.S. at 624, or differences in the state substantive laws that control various groups of claimants, see, e.g., Cole v. Gen. Motors Corp. 484 F.3d 717 (5th Cir. 2007) (differences in the claims of class members from various states rendered class certification inappropriate); In re Bridgestone/Firestone, Inc. Tires Prods. Liab. Litig., 288 F.3d 1012 (7th Cir. 2002) (finding that because the law of the claimants various states of residence applied, a nationwide class was unmanageable).

98 Just to be clear, by real-world data, I am not arguing that the non-removable state cases would provide data about the "right" result in any given case (to the extent that could even be a realistic goal of any litigation) or the "better" result in any given case, as compared with the result that would be reached in federal court. That said, appropriately sampled cases might well be more likely to generate better accuracy about the value of the claims in mass litigation than any single proceeding, consolidated or otherwise. See, e.g., Cheng, supra note 94, at 957-65. 
settlement outcome in relation to the merits of the suit. ${ }^{99}$ The distortions created 1 by inadequately robust data can lead, for instance, to the over-valuing in the settlement of relatively weak sub-groups of claims (perhaps "free-riding" on the backs of strong claims), or the "cramming down" of paltry settlement values by defendants who have, for instance, managed to engineer some form of "reverse 5 auction" of the aggregate set of claims. ${ }^{100}$

However, freed from the constraints of Rule 23, non-removable state proceedings in MDL could be harnessed to develop settlement grid criteria that could more robustly reflect real-world data about claim value as well as the divergences in claim value among different types of claimants, and/or among 10 claimants with varying characteristics within a larger mass dispute. Given the frequent existence of differing substantive state laws involved in mass litigation in general, and mass torts in particular-divergences that often cripple the achievement of global resolution of claims under Rule $23^{101}$-proceedings in state court could be used to obtain actual, real-world data about the strengths 15 and weaknesses of claims under different states' laws and thus a fuller picture regarding the range of values attendant those claims. Further, the data from state-court proceedings would emerge from a range of real-world conditionsconditions involving judges from different states, locally sourced juries (where relevant), and perhaps quite importantly, different state court procedures 20 against which the relevant substantive state laws were enacted. ${ }^{102}$ Deriving real-world data from state court cases would enable any ultimate resolution the opportunity to reflect the involvement of different decision-makers, judges

99 See J. Maria Glover, The Federal Rules of Civil Settlement, 87 N.Y.U. L. Rev. 1713, 1724-43 (2012) (discussing the various ways in which parties can obtain bargaining leverage, wholly irrespective of the merits of underlying claims).

100 See Erichson \& Zipursky, supra note 19, at 270-74, 318-20; John C. Coffee Jr., Accountability and Competition in Securities Class Actions: Why "Exit" Works Better Than “Voice," 30 CARDozo L. REv. 407, 432-35, 441 (2008) (discussing agency problems in aggregate 30 litigation); Richard A. Nagareda, Aggregation and Its Discontents: Class Settlement Pressure, Class-wide Arbitration, and CAFA, 106 Colum. L. Rev. 1872, 1879-82 (2006).

101 See, e.g., Phillips Petroleum Co. v. Shutts, 472 U.S. 797, 822 (1985) (finding that a Kansas state court had erred in deciding that Kansas law could govern all of the claims in a multistate class because the court did not determine that it had a "significant contact or aggregation of contacts" to the claims asserted by each member in order to ensure that the choice of Kansas 35 law was not arbitrary or unfair).

102 Indeed, "there remain important ideological correlates to the political [and geographical] lines within America.” See generally Cover, supra note 93, at 658, 665-66 (“[M]ost state court trial judges are drawn from local, provincial elites.... Levels of education, bonds of loyalty, status, and even economic class may differ radically from one group to another [and between state judges and federal judges].”). 
and juries, who comprise most decidedly real-world variants one would encoun- 1 ter were all cases to be tried individually. ${ }^{103}$ Then, to the extent the nonremovable cases could be, say, appropriately sampled and used as part of an overall effort for generating a global settlement in the mass dispute, ${ }^{104}$ and to the extent the real-world data generated becomes reflected in any ultimate 5 settlement grid, it may help mitigate the impact of non-merits-based distortions of settlement values. ${ }^{105}$

Second, real-world data from the non-removable state cases may be preferable, as a matter of settlement inputs, to data from single consolidated proceedings in the MDL or even data from bellwether trials ordered by the MDL judge 10 and conducted in various federal courts once consolidated pre-trial proceedings have concluded. Using independent state-court proceedings as test cases-both to develop a market for the claims and to obtain a sense of the claim-value distribution through the generation of real-world data about claims' strengths and weaknesses-has the potential to improve the quality of any ultimate 15

103 This is of course not to suggest that, ideally, all cases would be tried individually (ideally they would not). Rather, it is to argue that, in a world in which aggregate resolution of frequently large, nationwide problems is obtained through private litigation rather than some form of public legislation or regulation, the real-world outcome data about culpability on the part of defendants and entitlement to relief on the part of claimants is, by design, to emerge from the judicial process, and more specifically, from individual trials. The idea here is that selection of some appropriately sampled sub-set of the non-removable state proceedings (appropriate sampling is a topic beyond the scope of this Article) could provide us with the real-world data we would otherwise only get through trying all cases individually.

104 This Article leaves for another day work that would offer a method of sampling state cases for use in generating an ultimate settlement grid. At the very least, the process for selecting state cases to be harnessed as discipliners of the settlement grid should be aimed at selecting cases that will provide data about the overall distribution of claim strengths, weaknesses, and claim values. See generally Cheng, supra note 94, at 956-57, 965. Moreover, the state cases would arguably need to proceed as part of a coordinated plan for settlement design-a point that has numerous implications, not the least of which being that, as part of the plan, 30 defendants would not be permitted to settle out all of the strong cases that represented the high end of the distribution in order to distort the claim valuations of any ultimate settlement of the entire mass dispute.

105 See generally Glover, supra note 99, at 1713 (describing as a "distorted" settlement value one that fails meaningfully to reflect the values of claims as dictated by the contours of relevant substantive law). See also Cover, supra note 93, at 665 ("If outcomes are confirmed by the courts 35 of two or more different systems which vary with regard to supposed social determinants of knowledge and mind, this result would suggest some common epistemological ground with respect to the issue presented and with respect to its resolution. For a series of jurisdictional alternatives to present a plausible network of redundancy sufficient to 'correct' ideological bias requires that those alternative forums arise out of widely varied political bases with attendant variations in the constituencies to which they speak."). 
settlement by providing information derived from full test cases, as opposed to 1 say, test trials (more commonly known as bellwether trials). ${ }^{106}$ Indeed, various selected, independent cradle-to-grave parallel state proceedings can be seen as facilitators of, rather than impediments to, settlements in mass litigation through their provision of real-world data about the appropriate weight to attach 5 to particular evidence, such as expert testimony.

Such value can be illustrated by way of comparison to the likely alternative arrangement that would result from the adoption of the sorts of reforms suggested above-consolidation (formally or informally through consolidation of significant pre-trial matters) of state and federal cases for pre-trial proceedings 10 followed, potentially, by bellwether trials in selected federal district courts. Bellwether trials, and trials more generally-while no doubt capable of providing crucibles for the ultimate merits of a case and value of a given claimnecessarily incorporate and to some degree will be dictated by a number of crucial decisions made long before the trial commences. To collapse, for 15 instance, pre-trial decisions about the admissibility of experts into a single consolidated proceeding (even one in which both the federal MDL judge and state judges presiding over state cases can participate $)^{107}$ is to prevent the development of information regarding variances in outcome that would result from admission or exclusion of that expert's testimony. Perhaps the decision 20 whether to exclude or admit an expert's testimony in a single, consolidated proceeding would capture, without all the inefficiencies of multiple proceedings, precisely what would have happened had different decision-makers, applying different state's laws on expert evidence, approached the issue independently and, most likely, over some period of time. ${ }^{108}$ But that is likely to be so only in 25

106 See 28 U.S.C. § 1407(a) ("Each action so transferred [to an MDL] shall be remanded by the panel at or before the conclusion of such pretrial proceedings to the district from which it was transferred unless it shall have been previously terminated..."); see also Eldon E. Fallon, Jeremy T. Grabill, \& Robert Pitard Wynne, Bellwether Trials in Multidistrict Litigation, 82 Tul. L. Rev. 232330 (2008) (describing the increasingly common practice of bellwether trials in MDL).

107 See Barbara J. Rothstein, Francis E. McGovern, \& Sarah Jael Dion, A Model Mass Tort: The PPA Experience, 54 Drake L. Rev. 621, 632-35 (discussing the joint Daubert hearing in the PPA litigation in which the federal MDL transferee judge invited multiple state court judges with jurisdiction over overlapping claims in a "joint proceeding of the federal courts and the attending state court judge" that "considered the application of expert testimony to claimants 35 in various subpopulations").

108 See generally Byron G. Stier, Jackpot Justice: Verdict Variability and the Mass Tort Class Action, 80 Temp. L. Rev. 1013, 1063 (2007) (“[T]he use of individual juries [is superior because it] ... will track changes over time...”). Stier uses as an example the silicone breast implant mass litigation, in which he notes that a scientific consensus on the safety of silicone breast implants emerged only after Dow Corning, the major manufacturer of such implants, entered bankruptcy. 40 
the clearest of cases. Indeed, any single proceeding-even one in which various 1 state judges participate-risks, in establishing a settlement grid, according undue weight (or undue lack of weight) to, say, a particular expert's testimony. ${ }^{109}$

Moreover, even if the more common arrangement of conducting indepen- 5 dent bellwether trials in federal district courts after pre-trial matters are sorted out by the MDL judge were expanded to include bellwether litigation, pre-trial and all, state proceedings might still be a better source of real-world data for the settlement grid. As a real-world matter, state-law claims would be tested within the structure of the relevant state's procedural law on important pre-trial deci- 10 sions like motions to dismiss, expert admission, and summary judgment; the relevant law would be applied by a state judge more likely familiar with its contours and, perhaps in addition, by jury pools not necessarily drawn from the larger, often more urban areas encompassed by federal districts. Put somewhat over-simplistically, if one wishes to know how a state court, staffed with a state 15 judge and employing a jury pooled from the relevant geographic area, will find, there is no better mechanism by which to obtain that knowledge than by conducting proceedings in that state court, in front of that state judge, in front of that state jury. ${ }^{110}$ Indeed, no matter how closely (or even perfectly) a federal judge might discern (or extrapolate from existing state opinions on the issue) a 20 state's interpretation of its own substantive laws, a diversity of real-world data from pre-trial decisions is less likely to emerge from a single MDL judge applying various state substantive laws against the backdrop of federal procedural rules

See B. J. Feder, "Dow Corning in Bankruptcy over Lawsuits," N.Y. Trmes, at A1 (May 16, 1995) (describing Dow Corning seeking protection of bankruptcy to deal with claims worth billions of dollars); Food \& Drug Admin, FDA BREAST Implant Consumer HandBook 68-69 (2004), available at http://www.drfisher.com/cosmeticsurgery/Breast/breastaug/fdabreastprosthesis.pdf (noting that in 1999 Institute of Medicine concluded there was "insufficient evidence" of systemic health concerns from silicone and saline breast implants).

109 By way of extreme (and highly stylized) example, the weight of, say, Stephen Hawking's expert testimony on particle physics-and therefore its influence on the value of a claim that depended in any meaningful way on that testimony-is statistically worth a great deal (say 1.0, or $100 \%)$. In contrast, my expert testimony on such matters assuredly must be somewhere around 0.0. Absent such clear (or nearly as clear) dichotomies, the effect of a single Daubert hearing in mass litigation is tantamount to ascribing either $100 \%$ or $0 \%$ weight to that expert's 35 opinion, and more importantly to affect significantly the value of the claims dependent on that testimony as reflected in an ultimate settlement grid.

110 See Cover, supra note 93, at 658, 665-66 (discussing how "to the extent that the jurisdictional alternatives differ with respect to the supposed salient social determinants of ideology," presumably with the different judges or juries that will be involved with each jurisdiction, "complex concurrency constitutes a strategy for coping with ideological impasse"). 
than from a variety of state courts applying their state substantive law against 1 the backdrop of their own, often divergent state procedural rules. This realworld data, depending on its contours, may reveal necessary correctives and adjustments in an ultimate global settlement in the MDL proceedings, thereby aiding in the creation of fairer settlement terms. Conversely, that data may 5 strengthen any views about an ultimate settlement developing in the MDL, and perhaps thereby better guarantee its finality. Either way, the real-world data would prove quite valuable.

\section{B Legitimacy of mass litigation governance}

When mass litigation is viewed through the lens of governance, one can see an obvious tension between, on the one hand, the common mechanism of that governance-settlement grids that, by often purporting to resolve the claims of 15 scores of citizens, spread throughout the country, on issues that frequently affect national markets, start to resemble administrative regulatory schemes ${ }^{111}$ and, on the other hand, the "regulatory authority" of the principal authors of that governing mechanism - private attorneys, and, in the MDL context, a single MDL judge. ${ }^{112}$ This tension raises important, first-order law-making questions about 20 the permissible scope of a single tribunal's power over matters of national

111 See, e.g., NAGAREDA, supra note 4, at 76-80 (comparing the sought-after settlements in class actions to things like workman's compensation regulatory schemes).

112 It is worth noting a bit of irony here: To the extent courts have held that judges lack the authority to engineer grand compromises by way of settlement grids-grids based on very carefully thought-out sampling methods intended to ensure adequate representation of plaintiffs and adequate exploration of differences among them and their claims-it seems quite counter-intuitive, from a governance standpoint, to give private parties free reign to do so without at least as much attention given to the way in which the settlement is reached. See, e.g., Cimino v. Raymark Indus., 151 F.3d 297 (5th Cir. 1998) (rejecting a three step trial plan instituted 30 by District Judge Parker to resolve asbestos litigation whereby (1) a jury would decide which, if any, of each of the defendants products were defective, (2) the same jury would determine both the extent and nature of injuries in the class and full liability determinations for the named class representatives, as well as up to 15 additional plaintiffs chosen from each side of the litigation, and (3) the court would distribute the awarded damages among the individual class members according to the jury's findings regarding the sample claimants); see generally id. at 35 321 (“"The argument is sensibly made that a nationwide administrative claims processing regime would provide the most secure, fair, and efficient means of compensating victims of asbestos exposure. Congress, however, has not adopted such a solution.' ... The Judicial Branch can offer the trial of lawsuits. It has no power or competence to do more." (quoting Amchem Prods., Inc. v. Windsor, 521 U.S. 591.621 (1997))). In any event, that irony currently seems lost on (or irrelevant to) the Supreme Court, whose jurisprudence in the area of contractual class action 40 
concern, and questions about what private attorneys, through the MDL process, 1 may appropriately do, and what legislatures alone may do. ${ }^{113}$ At bottom, given the undoubtedly regulatory role being played by judges and private attorneys in mass litigation, ${ }^{114}$ the negotiated settlements may constitute legitimate governance only to the extent that they operate within what might be loosely called 5 their "delegated" scope of authority: the redressing of wrongs through private enforcement of judicially developed or legislatively enacted substantive law. Indeed, using state cases to develop the real-world data points for maturation of claims and about the strength and weaknesses of claims under various state substantive laws could, in disciplining any resulting settlement grid, help legit- 10 imize what amounts to that settlement's representation of the exercise of regulatory authority, for at least two reasons.

First, at least to the extent the relevant substantive law is state law, harnessing the public courts of the various states in this manner arguably renders the creation and enforcement of the resulting settlement grid more firmly and 15 explicitly within the judicial power-namely, the power to provide claimants with access to law that defines wrongs and provides remedies for those

waivers suggests a reluctance to place any limits whatsoever on the ability of private parties to effectively contract around liability and, in so doing, to potentially effectuate something resembling reconfiguration of legislatively-enacted remedial schemes. See, e.g., Am. Exp. Co. v. Italian Colors Restaurant, 133 S.Ct. 2304 (2013) (finding that there was no congressional action sufficient to require the rejection of a class-arbitration waiver on the grounds that it altered the substantive rights of the claimants or prohibited the effective vindication of their rights); AT\&T Mobility LLC v. Concepcion, 131 S.Ct. 1740 (2011) (finding that the Federal Arbitration Act preempts California's judicial rule regarding the unconscionability of class action waivers in consumer contracts); Shady Grove Orthopedic Assocs., P.A. v. Allstate Ins. Co., 559 U.S. 393, 408 (2010) (declaring that the class action device did not bear on substantive rights as "[s]uch rules neither change plaintiffs' separate entitlements to relief nor abridge defendants' rights; they alter only how the claims are processed"); Stolt-Nielsen S.A. v. AnimalFeeds International Corp., 559 U.S. 662, 668-70 (2010) (finding that an arbitration agreement that made no specific mention of class proceedings could not be read to establish class-wide arbitration).

113 In-depth exploration of these first-order questions is beyond the scope of this article, though I have explored the topic somewhat in prior work. See, e.g., J. Maria Glover, The Structural Role of Private Enforcement Mechanisms in Public Law, 53 WM. \& Mary L. Rev. 1137 (2012); J. Maria Glover, Note, Beyond Unconscionability: Class Action Waivers and Mandatory Arbitration Agreements, 59 VAND. L. Rev. 1735 (2006).

114 See John Fabian Witt, Bureaucratic Legalism, American Style: Private Bureaucratic Legalism and the Governance of the Tort System, 56 DEPAUL L. Rev. 261 (2007) (“[T]he modern plaintiffs' bar serves a crucial regulatory function in American public policy...”). Witt also described the plaintiffs' bar as possessing an immense regulatory role in the tort system-as a "private bureaucracy" too frequently "decentralized ... virtually invisible ... and unconstrained." Id. at 261-62. 
wrongs. ${ }^{115}$ (This is, of course, to put to the side the more mundane question of 1 whether a given court might find, quite formalistically I would argue, that the explicit use of cases (state or otherwise) to inform potential settlement negotiations and an ultimate settlement is a bridge too far, at least under current doctrine.) ${ }^{116}$ In short, these state cases could be harnessed for the express 5 purpose of ensuring that the relevant public institutions-the government-has "done its job" 117 vis-à-vis mass litigation.

Second, while the efficiency gains of wholesale consolidation or coordination along the lines suggested in Part II are by no means unimportant, there is potential value-as a matter of democratic legitimacy vis-à-vis regulation-in the 10 purposeful tolerance of inefficiency, in the purposeful use of "redundant" state proceedings. Perhaps most fundamentally, the involvement of multifarious decision-makers in mass litigation dilutes the concentration of power in a single decision-maker over matters that are frequently wide-reaching in their geographic scope. As Robert Cover has recognized, jurisdictional redundancy is, 15 at a fundamental level, a "structural solution" that tends to relieve either the presence of, or even perception of, corruption in a single decision-maker; multiple proceedings provide a check against potential distrust-justified or not-of a single forum. ${ }^{118}$ Purposefully allowing for independent state proceedings and incorporating those cases into an overall approach to the mass litigation would 20 have the effect of requiring each separate state, as well as the distinct state and

115 See John C.P. Goldberg, Ten Half-Truths About Tort Law, 42 VAL. U. L. Rev. 1221, 1265 (2008) (noting that tort law can (and should) be reflected in an ultimate settlement through test cases that reveal patterns as to the strengths and weaknesses on various substantive elements, such 25 as "defect, causation, comparative fault," and thus reveal patterns regarding the strengths and weaknesses of different claims); Glover, supra note 99 (calling upon the judiciary to perform more of its traditional adjudicative functions for the express purpose of facilitating settlements that more accurately reflect the dictates of underlying substantive law); see also generally Jonathan T. Molot, An Old Judicial Role for a New Judicial Era, 113 YALE L.J. 27 (2003) (describing the significant adjudicatory role that the judiciary could return to and play in aggregate dispute 30 resolution).

116 See, e.g., Cimino v. Raymark Indus., 151 F.3d 297 (5th Cir. 19998) (rejecting a trial plan whereby test trials of individual claimants would be explicitly determinative of the recovery of individual claimants); see also Wal-Mart Stores, Inc. v. Dukes 131 S. Ct. 2541, 2555 (2011) (discussing how plaintiffs' statistical evidence, proffered to demonstrate commonality between class members, fundamentally failed to demonstrate that commonality exists even if entirely 35 credible).

117 Goldberg, supra note 115, at 1266.

118 Cover, supra note 93, at 661 (discussing how jurisdictional redundancy can act as a structural solution to corruption or the suspicion of corruption in a tribunal); see also id. at 669 (identifying, in many criminal prosecutions, mistrust of the original, state-based decisionmaker as the basis for developing or invoking an alternative federal forum to the relevant state). 40 
federal systems, to be more attentive to one another's approaches and views of 1 the legal norms at issue once endeavors for an ultimate settlement begin, ${ }^{119}$ thus providing a structural check on the regulatory power of a single tribunal and single set of attorneys. Moreover, at least (and especially) insofar as the substantive law forming the basis for the claims in mass litigation is state law, such 5 heightened attention to others' approaches may well imbue any resulting deal with greater regulatory legitimacy, inasmuch as it was crafted through a process that solicited, and ideally, incorporated, input not just from a single tribunal working alongside a small, select set of private attorneys, but from the various relevant tribunals and a larger group of attorneys.

Relatedly, the exportation onto the nation of a single tribunal's approach to matters affecting citizens in various states has the potential to deprive any resulting settlement of the ability to reflect possibly divergent views regarding the relevant legal norms that would emerge were the different constituencies permitted through the non-removable state proceedings to express those 15 views. ${ }^{120}$ To the extent fissures emerge in claim valuation (after a claim-maturation process), the state cases will have provided not just a mechanism for greater democratic participation through local litigation proceedings, but they will also have provided useful evidence of potentially needed dividing lines in any ultimate global settlement. To the extent the full-dress state proceedings reveal 20 a great deal of consensus, the value of the redundancy is no less powerful. While confirmatory results could be viewed as evidence in support of the need for more efficient, consolidated proceedings, those confirmatory results-emerging from differing tribunals-could be viewed instead as strengthening the legitimacy of any ultimate global settlement that reflected the data generated 25 by those cases. ${ }^{121}$

\section{Settlement fairness}

It is also possible that parallel state cases in mass litigation-again, if appropriately selected-could be harnessed for purposes of enhancing the fairness of any resulting settlement. To be sure, fairness is a relatively amorphous, and

119 See id. at 680.

120 See id. at 658 ("The political subdivisions of America do indeed present a range of policy initiatives differing both in terms of conditions to be met and ways of meeting them.").

121 See id. at 675 (noting that multiple consistent pronouncements of a legal norm "removes jurisdictional doubt," and "reduces the likelihood that the conclusion was the product of local error or prejudice, ideology or interest”). 
almost always slippery, concept. Here, I largely mean fairness in the following 1 two senses: First, as articulated by Richard Nagareda, peace arrangements, such as settlement grids, ought to "allocate [settlement] value equitably among claimants." 122 And by "equitably," I refer primarily to the notion that such value is allocated according to the satisfaction of settlement criteria as identified 5 through test cases and according to the strengths of a plaintiff's (or, more likely, set of plaintiffs') particular type of claim-and not, I might emphasize, according to the sometimes troubling representational incentives of, say, a small set of plaintiffs' or defense attorneys. ${ }^{123}$ Second, peace arrangements should be the result of a process structured such that heightened attention is given to the 10 alignment of incentives between attorneys and clients.

On these scores, again, the "happenstantial" consequences of federalismthose parallel state proceedings-may not be all bad from the standpoint of mass litigation resolution. First, insofar as a set of plaintiffs properly brings claims under a particular state's laws-even if, and perhaps especially if the laws of 15 that state, both substantive and procedural, provide greater protection, relief, and/or ease of access to either-a "fair" settlement grid would account for those realities, out of fairness to those litigants. The converse likewise would be true: To the extent sets of claimants are not protected by such plaintiff-friendly laws, a "fair" settlement grid would not allocate compensation to all claimants in 20 accordance with the dictates of the strictest state law. ${ }^{124}$ In this sense,

122 NAGAREDA, supra note 4, at 223.

123 As examples, absent competition, a plaintiffs' steering committee in MDL may be incentivized to avoid risk and settle plaintiffs' claims for less than could be obtained should those 25 plaintiffs sue individually. See Coffee, supra note 100, at 409, 413-14. This problem may be ameliorated in large part by the introduction of competition, see id. at 415-16, at least insofar as competition is policed to avoid reverse auctions of plaintiffs' claims. Conversely, defendants' attorneys will rationally seek to settle any test cases that could drive up settlement values in an ultimate grid and try only the "easy-to-win" cases. This second problem is one that could arise with or without the use of non-removable state proceedings and calls for careful selection, 30 development, and execution of test cases-no matter where they are sourced-to be addressed. This Article thus does not suggest that mere recognition of the potential for state cases to be used to, say, generate settlement data, would ameliorate this problem of defendant-attorney incentives. That problem goes more directly towards questions of case sampling, which are beyond the scope of this project.

124 To be sure, given any number of strategic maneuvers, individuals may be able to obtain 35 access to the laws of a state that developed with no intent to protect that particular individual (perhaps a non-citizen) or to deter the conduct of the defendant at the behest of a suit brought by that individual. For purposes of this article, I set aside the persistent, largely undesirable, though likely inevitable reality of jurisdictional strategy and gamesmanship as a largely separate problem for another day. I leave that problem (for now) in the hands of the jurisdictional doctrines and rules that attempt to reign in some of that gamesmanship. 
harnessing "happenstantial federalism," by recognizing and effectuating the 1 substantive and procedural differences among cases and claims, could arguably part of what it means for outcomes to be "fair." Specifically, independent state proceedings could be used to better identify those differences among claims and claimants ${ }^{125}$ (and particularly those that derive from differences in state law, 5 state court procedures, and the values and norms of locally-sourced juries), thus providing the various subsets of claimants, as well as defendants, with bargaining leverage vis-à-vis settlement grid design and implementation that comports more closely with real-world data about the value of the claims themselves.

Data that reflects differences among claims and claimants could be particu- 10 larly important to the fairness of any resulting settlement, given that global resolution of mass litigation frequently (if not always) constitutes some form of "grand compromise."126 Again drawing upon lessons from the class action context, both Rule 23 and the interpretations of its requirements reflected efforts to ensure that any such "grand compromise" does not unduly sacrifice, or "sell 15 out" a given sub-set of claimants in favor of another sub-set. ${ }^{127}$ Of course, the

125 See supra Part III.A. and accompanying text.

126 NAGAREDA, supra note 4, at 94.

127 This dynamic of aggregate resolution is a recurring theme in the class action context. In the Supreme Court's decision in Amchem Products, Inc. v. Windsor, for instance, the court found that "[i]n significant respects, the interests of those within the class are not aligned," as it purported to settle the claims of those currently injured, who needed immediate, generous payouts, and those who were only exposed to asbestos, but did not yet contract any related illnesses, and wished to preserve an "ample, inflation-protected fund for the future." See 521 U.S. 591, 595 (1997). In Amchem, at least some of the attention given to protecting the interests of such future claimants was likely attributable to the desire of plaintiffs' attorneys, not appointed class counsel, to preserve their inventory of clients, and, along with that inventory, their livelihood, rather than a decision to disadvantage the currently injured plaintiffs. Nevertheless, the fear that class settlements, or class counsel, will favor particular groups of claimants at the expense of others is often a significant consideration in deciding whether to certify a class, especially if the court can identify distinguishable subsets of claimants whose interests cannot be said to align with those of any particular named plaintiff. See, e.g., Safeco Ins. Co. v. Am. Intern. Group, Inc., 710 F.3d 754, 757 (7th Cir. 2013) (acknowledging that "conflicts of interest between representative plaintiffs and class members can lead the representatives to sell out for too little”); Broussard v. Meineke Discount Muffler Shops, Inc., 155 F.3d 331, 337-38 (4th Cir. 1998) (discussing how "conflict[s] of interest between different groups of" claimants with respect to the appropriate relief can disadvantage particular claimants); In re 35 Gen. Motors Corp. Pick-Up Truck Fuel Tank Prods. Liab. Litig., 55 F.3d 768, 801 (3d Cir. 1995) (discussing how a court must carefully evaluate class settlements to determine whether "the decision to settle represents a good value for a relatively weak case or a sell-out of an otherwise strong case"); In re Ford Motor Co. Bronco II Prods. Liab. Litig., 1995 WL 222177, *4-`5 (E.D. La. Apr. 12, 1995) (rejecting a class settlement that gave plaintiffs alleging defects in the Ford Bronco II, rather than the many forms of compensation and damages sought in their complaint, 40 
degree to which such differences should be sublimated in the name of efficiency 1 may depend on the degree to which the individual claims are marketable, or litigable. In the context of Rule 23 , these protections arguably have been misused to harm plaintiffs by making the ideal of access to individual process an impediment to the effective vindication of individually unmarketable claims. ${ }^{128} 5$

For plaintiffs who cannot avail themselves of the class action device, the lack of a grand compromise settlement grid may well mean lack of any compensation for their claim at all. On one hand, the need for (and, frequently, inevitability of) such a "grand compromise" in mass litigation may well support removing state cases into federal MDL proceedings for purposes of facilitating 10 the ultimate grand compromise by getting all of the claims in one place and under the management of a single judge, a plaintiffs' steering committee, and the relevant defense counsel. On the other hand, and perhaps particularly given

a "utility vehicle video, a sun-visor warning sticker, a utility vehicle Owner's Guide Supplement, and an inspection of their vehicles," but did provide for considerable attorney's fees for class counsel).

Indeed, the notion that class conflicts had the potential to advantage certain groups of claimants over other groups contributed to the Supreme Court's reasoning in General Telephone Co. v. Falcon, when it de-certified an class of Mexican-American claimants alleging employment discrimination in both hiring and promotion decisions. 457 U.S. 147 (1982). There, the named plaintiffs' claim did not depend in any way on "the failure of [the defendant] to hire more Mexican-Americans," because he had been hired. Id. at 158. Accordingly, it was not safe to assume that he would pursue the interests of claimants alleging discrimination in hiring as aggressively as those of similarly situated claimants. As feared, in other cases, class settlements have explicitly attempted, usually unsuccessfully, to engage in this type of favoritism. See, e.g., 25 Nat'l Super Spuds, Inc. v. NY Mercantile Exch., 660 F.2d 9 (2d Cir. 1981) (Friendly, J.) (rejecting a class settlement alleging wrongful conduct that had depressed the price of potato futures contracts because it provided a recovery only for persons who had liquidated their holdings in a given time but purported to release the claims of individuals who had or had not liquidated during the time period); In re Gen. Motors Corp. Engine Litig., 594 F.2d 1106, 1133-34 (7th Cir. 1979) (rejecting a class settlement that purported to release the federal claims of absent class members even if they refused to agree, effectively forcing absent members who disapproved of the settlement terms into an "accept-or-else" situation).

128 Unsurprisingly, such "protections" (or, perhaps, over-protections) have not gone without criticism. See, e.g., Elizabeth J. Cabraser, The Class Action Counterreformation, 57 Stan. L. Rev. 1475, 1476 (2005) ("In the case of Amchem, the perfect was the enemy of the good: the multibillion-dollar settlement, rejected by the Supreme Court, was lost forever, and thousands of 35 claimants who would have gladly traded their pristine due process rights for substantial monetary compensation have been consigned to the endless waiting that characterizes asbestos bankruptcies.”); Amchem, 521 U.S. at 630-32, 635-36 (emphasizing the importance of compensation for victims of asbestos exposure in the protracted and often delayed litigation of asbestos claims and questioning the majority's strict insistence that the conditions for class certification be satisfied prior to any consideration of the settlement's fairness). 
the absence of any of Rule 23's strictures in non-class mass litigation, allowing 1 some independent state court cases to proceed independent of the MDL could provide some protection of settlement fairness. For starters, in the class action context, plaintiffs sacrifice things like control over counsel, litigation proceedings, and even sometimes choice of law in an often-justifiable exchange for the 5 economies of scale and bargaining power associated with class certification.

It is less clear that such terms of exchange typify the universe of state claims running parallel to federal MDL. Empirical work on the question is needed, but it seems intuitively correct, and supported by the functioning of the marketplace for legal services, that where individual claims have been brought by a lawyer 10 on behalf of a plaintiff, either the lawyer, the client, or both have made a determination that the claim is worth the cost of pursuing it. ${ }^{129}$ Thus, at least on that score, the case for removal is less compelling, as the "grand compromise" would be vulnerable to the criticism that state plaintiffs traded far too much for the greater good, or perhaps more pointedly, the plaintiffs' steering 15 committee. At the very least, test proceedings of different types of claims in various state courts could be used to provide some modicum of process-based assurance that sub-groups of claimants were not favored at the expense of others at the settlement table. Independent litigation of cases in state courts, in other words, could be harnessed as important processes by which differences 20 among groups of claimants were identified, tested in a real-world way, and (presumably) used to inform any resulting settlement grid.

Crucially, and relating directly to the alignment of attorney-client incentives, the fairness advantages potentially achievable through the use of state-court test proceedings as settlement inputs could be bolstered by the involvement, in the 25 state proceedings, of various (and often rival) plaintiffs' firms. ${ }^{130}$ Fundamentally, involving various plaintiffs' firms introduces a modicum of competition into the market for the various claims in the mass litigation.

Drawing again upon lessons from the class action era, absent competition, class attorneys have "broad and unconfined discretion" unmoored from any 30 "meaningful principal/agent relationship." ${ }^{131}$ Without this relationship-without this client control-the lesson from the class action landscape is that the

129 To be sure, many state claims that relate to ongoing MDL proceedings are brought by the same plaintiffs' firms, raising the need for empirical inquiry into the extent to which, absent an 35 inventory of multiple plaintiffs by a particular firm, any individual case would or would not be filed.

130 See NAGAREDA, supra note 4, at 236-68; Witt, supra note 114, at 282-90 (both stressing the importance of inter-attorney competition and/or more policing of attorney practices in the area of mass torts).

131 Coffee, supra note 100, at 411. 
plaintiffs' attorney “will predictably deviate from the client's preferences to 1 pursue the attorneys' own interests ... risk preferences, and incentives"132 (including collusion with defense counsel). The dynamics of MDL counsel selection and representation may well be similarly misaligned with client interests. ${ }^{133}$ As John Coffee has traced, however, at least in securities class actions, 5 class members who opted out and pursued their claims individually performed much better, at least in terms of payout. ${ }^{134}$ Those opt-outs-that competitionhas the potential not only to improve outcomes for individuals, but also to improve settlement terms for the group overall. ${ }^{135}$ The non-removable state cases in MDL are, yet again, a readily available source of the very sort of 10 competition that holds the potential to improve outcomes for individuals and the group alike. To the extent the design of a test-case apparatus is done in a way that involves a variety of plaintiffs' law firms, and, crucially, that provides those attorneys with a corresponding proportional stake in the litigation, "peace" will be less likely to be purchasable on the cheap.

Moreover, through the use of various attorneys in state-court proceedings, the differences that often create disabling "intra-class conflicts" in the context of traditional class actions could be transformed from settlement obstacles to settlement facilitators in the context of the MDL process. For starters, the differing strategies employed by these firms could contribute to the generation of a more 20

132 Id. at 412-13.

133 Silver \& Miller, supra note 24, at 107, 109-10 (2010) ("Because MDL judges select lead attorneys and control their compensation, lead attorneys rarely challenge them. In practical effect, MDL judges are lead lawyers' clients. Fee-related concerns also cause non-lead lawyers to fear MDL judges, who take from them the money lead lawyers receive. By challenging an MDL judge, a non-lead lawyer must be willing to risk retribution in the form of a heavy fee tax. Because judges leave the size of forced fee transfers open until litigation ends, obedience is the prudent course for non-lead lawyers until an MDL formally concludes-or even longer when non-lead lawyers have cases in other MDLs being handled the same judge.”); see also S. Todd Brown, Plaintiff Control and Domination in Multidistrict Mass Torts, 61 CLEv. ST. L. Rev. 391, 40230 (2013) (discussing how, when lead counsel and the steering committee are being selected in an MDL, "[a] critical objective ... is to ensure that the lawyers work together and advance the collective interests of the claim pool in a cohesive fashion" and describing the disincentives for open competition for such roles).

134 Coffee, supra note 100, at 409 \& n. 7 ("That 'exit' may work better than 'voice' is evidenced by the striking disparity that has recently arisen between the modest payouts to class members 35 who remain in the class versus the much higher returns to institutional investors who opt out and sue in individual actions.").

135 See id. at 440-41 (“[I]ncreased opting out will place class counsel under increased competitive pressure to improve the class settlement. Faced with competition and a risk that a 'cheap' settlement will produce a high rate of opt outs, class counsel must seek to reach a superior settlement in order to avoid the fee reduction that follows from a smaller class size caused by increased opt outs.”) 
robust picture about the real-world value of claims-values that can vary, for better 1 or worse, in line with the skill, choices, and incentives of the relevant attorneys. Thus, the involvement of multiple firms, proceeding independently in uncoordinated proceedings, is a potential mechanism of settlement development, at least to the extent real-world data could be used to facilitate settlement valuations. 5 Further, by setting up a test-case structure that provides different attorneys with the opportunity to litigate on behalf of identified sub-groups of plaintiffs and subtypes of claims, yet still receive a stake in the ultimate settlement, the likelihood that a greater number of plaintiffs, not just a sub-set of plaintiffs, are represented at the bargaining table, increases. Again, just as the non-removable state cases 10 provide a check against the power of a single tribunal, similarly, those state cases and the corresponding variety of attorneys could be harnessed to provide a check against the power of a single set of attorneys over any ultimate settlement.

\section{Settlement finality}

Flowing from the above notions about real-world data, litigation governance, and settlement fairness is the promise of those proceedings to serve as guarantors of that settlement's finality. In this regard, at least two points deserve mention. First, as a theoretical matter, settlement outcomes that are the product of a process involving the views of different, independent decision-makers and enable greater representation of claimant sub-sets at the bargaining table are more likely to be accepted as legitimate by all involved. Put simply, to the extent that state-court cases facilitate settlements informed by real-world data that constitute a more legitimate and fair exercise of litigation governance, they will also promote the finality of those settlements.

On a more practical level, harnessing state-court cases as potential test cases may facilitate the finality of settlements because both the plaintiffs and the lawyers in those cases may have a greater incentive to take part in a global settlement-as opposed to opting out or objecting to the deal-if their case has played some role in influencing the overall deal. In other words, a settlement in which potentially value-impacting differences among plaintiffs have been tested and accounted for, and in which potentially rival plaintiffs firms are involved and given a stake, is more likely to be accepted (not in a coercive way) ${ }^{136}$ by

136 See, e.g., Howard Erichson, The Problem with All-or-Nothing Settlements, 58 U. Kan. L. Rev. 979 (2010); Richard A. Nagareda, Closure in Damage Class Settlements: The Godfather Guide to Opt-out Rights, 2003 U. ChI. Legal F. 141, 143 (2003) (describing coercive settlements as "Godfather"-type deals because the double-edged meaning of “an offer he can't refuse" stands as an apt description of an issue at the forefront of class settlement design). 
plaintiffs and their lawyers. Indeed, such a settlement may well be less vulner- 1 able to the phenomenon, seen frequently in the context of class action context, of deal-busting opt-out efforts by plaintiffs' attorneys not appointed class counsel. $^{137}$

Obtaining acceptance by litigants of these settlements, and thereby finality 5 of those settlements, through more democratically legitimate and fair design is not only crucial as a matter of efficiency considerations like docket management, or even as a matter of setting litigant expectations, but also as a matter of securing compensation for plaintiffs, and providing peace for defendants. Indeed, the notion of finality brings us full circle to the overall project of mass 10 litigation governance writ large. The harms involved in mass litigation typically occur on a nationalized (and even globalized) level. Accordingly, harnessing state-court litigation proceedings to inform, influence, and-perhaps depending on the precise operating structure for a mass litigation system so conceiveddictate the contours of a resulting settlement would arguably provide the closest 15 approximation of what constitutes a national approach, as defined by its substantive laws and underlying policy choices, to the relevant issues at hand, without simultaneously risking running afoul of the confines of legitimate exercise of regulatory authority. This is not to take a normative stand on the desirability of such a state of affairs-again, issues of national concern may well 20 call for correspondingly national law. It is rather to argue that the more a mass litigation settlement tracks either the common law or legislatively enacted statutory law of the relevant states, and the more that settlement reflects the dictates of those laws, the procedural backdrops against which those laws are enacted and enforced, and the input of the judicial officers and community 25 members of those states as components of the adjudicative process, the more that settlement embodies the sorts of features-democratic accountability, faithfulness to governing law, democratic participation, to name a few-typically associated with legitimate exercises of public governance.

To be clear, none of the foregoing is meant to suggest conclusively that statecourt proceedings are the only means, or even the best means, of obtaining the coordinated redundancy that could facilitate mass litigation governance. Rather,

137 See, e.g., Rhonda Wasserman, Dueling Class Actions, 80 B.U. L. Rev. 461, 498-505 (2000) (discussing how the competition between overlapping class actions filed in Delaware Chancery Court and the Central District of California by plaintiffs attorneys seeking to control the litigation frustrated the class' preclusive effect in Epstein v. MCA, Inc. and related litigation); see also William T. Allen, Finality of Judgments in Class Actions: A Comment on Epstein v. MCA, Inc., 73 N.Y.U.L. REv. 1149 (1998). 
I offer these thoughts about non-removable state cases in MDL principally to 1 broaden the debate to include consideration of the ways in which these state cases might be harnessed in service of achieving long-elusive goals of mass litigation settlements. In addition, suggesting that "happenstantial federalism" could play an unrecognized and potentially important role in the resolution of 5 mass litigation is certainly not to reject wholesale the need for consolidation and coordination of federal and state proceedings. Indeed, quite the opposite. As mentioned above, harnessing the state-court proceedings to facilitate mass litigation governance ought to be done deliberately, cooperatively, and with careful attention to issues of sampling and selection-the latter raising a number 10 of issues beyond the scope of this Article. That said, in conclusion, I offer a few very preliminary thoughts on the mechanics of a "mass-litigation cooperative redundancy" regime that would harness independent state and federal proceedings in mass litigation. These thoughts are of course far short of a model for structuring state and federal proceedings in mass litigation; rather, they are 15 preliminary observations about what such a structure might look like.

For starters, the coordination needed among state and federal courts in the joint enterprise of achieving global resolution of claims through settlement may be less achievable in the absence of the development, by more states, of internal procedures for consolidation and coordination of related cases within their own 20 state dockets. Currently, states run the gamut from those with formalized mechanisms for consolidation ${ }^{138}$ to those with virtually none. ${ }^{139}$ As a helpful prerequisite to inter-systemic coordination of any sort, it would perhaps be helpful, at the very least, for the state judiciaries that must coordinate, communicate, and participate in joint effort with other entities-namely, other state 25 judiciaries and federal judges presiding over related claims-to coordinate consolidate, and organize amongst themselves, rather than place the bulk of the organizational burden on parties (and specifically, defendants, who know where they are being sued).

Beyond that, harnessing state and federal cases to create real-world data 30 points for a settlement grid would likely call for coordination and communication among all relevant judges, at the outset of the overall litigation process, to monitor, discuss, and perhaps even design a regime of test cases both for developing the market for claims (if such claims are not yet mature) and for generating data for an ultimate settlement. Test cases would be conducted in a 35 way specifically designed to identify the relevant distribution of claim ranges,

138 See supra note 32 and accompanying text.

139 See supra note 35 and accompanying text. 
with special attention to the incentives of defendants' attorneys to settle poten- 1 tially high-value cases and only to take low-value, or low-probability-success claims to trial. The form of such coordination could, for instance, take the form of a panel of judges, state and federal, who together meet to identify the differences among claims, claimants, plaintiffs' firms, etc., that seem most likely 5 to generate differences in outcome, and by extension, settlement values or settlement eligibility criteria, or both. Once such determinations are made (and this is of course vastly oversimplified), the panel, perhaps in consultation with various plaintiffs' firms, defendants, and experts on statistical sampling methods, could order a series of cases to proceed cradle to grave-pre-trial through 10 trial-in various courts. Such proceedings would occur independently and with the express understanding-and, indeed, the express aim-that some decisions will be made more than once, by multiple decision makers. Certain pre-trial tasks will be duplicated on purpose, in service of effectuating the values of litigation governance discussed above.

After test proceedings have concluded, perhaps the initial panel of state and federal judges could reconvene to facilitate the formation of a settlement grid. Such an undertaking may well require Congressional blessing, so as to insulate resulting settlement agreements from the dismantling encountered by those created in the class action context. Short of that, the federal and state judges 20 could conduct these proceedings, leaving it ultimately to the parties themselves to design any ultimate settlement grid, but understanding that those proceedings will no doubt produce crucial data for the creation and constraining of a privately-designed settlement grid.

\section{Conclusion}

Outside the long-standing, comfortable, though at times constraining terrain of the class action device, the world of mass litigation in some ways finds itself in a new stage of infancy. From that starting point, this paper certainly asks more questions than it answers. As litigation grows increasingly complex in nature and scope, and as formalized mechanisms for resolution fall in and out of favor, this Article adds new thoughts and theories to the specific debate regarding parallel state and federal claims in MDL, as well as to the larger debate about mass litigation governance in a post-class action world.

Acknowledgment: For their thoughtful commentary on this piece, I would like to thank Tracey George, Bill Rubenstein, and Patrick Wooley. I would also like to 
thank Lynn Baker, Elizabeth Chamblee Burch, Robin Effron, Derek Ho, Larry 1 Solum, David Super, David Vladeck, Brian Wolffman, Kathy Zeiler, and the participants at The Public Life of the Private Law: The Logic and Experience of Mass Litigation conference for their insightful comments. Marc Werner, Logan Dwyer, and T.J. McCarrick provided excellent research assistance. 